\title{
1 Temporal trends in hospitalizations and 30-day mortality in older patients 2 during the COVID pandemic from March 2020 to July 2021
}

3 Sara Garcia-Ptacek MD, $\mathrm{PhD}^{1,2^{*}}$, Hong $\mathrm{Xu} \mathrm{MD,} \mathrm{PhD}^{1}{ }^{*}$, Martin Annetorp $\mathrm{MD}^{2}$, Viktoria Bäck

4 Jerlardtz $\mathrm{MD}^{3}$, Tommy Cederholm MD, $\mathrm{PhD}^{1,2}$, Malin Engström $\mathrm{MD}^{4}$, Miia Kivipelto MD, $5 \mathrm{PhD}^{1,2}$, Lars Göran Lundberg $\mathrm{MD}^{5}$, Carina Metzner $\mathrm{MD}^{2}$, Maria Olsson $\mathrm{MD}^{6,7}$, Josefina 6 Skogö Nyvang MD, $\mathrm{PhD}^{8}$, Carina Sühl Öberg $\mathrm{MD}^{9}$, Elisabet Åkesson MD, $\mathrm{PhD}^{10,11}$, Dorota 7 Religa $\mathrm{MD}, \mathrm{PhD}^{1,2}$, Maria Eriksdotter $\mathrm{MD}, \mathrm{PhD}^{1,2}$

${ }^{1}$ Division of Clinical Geriatrics, Department of Neurobiology, Care Sciences and Society, Karolinska Institutet, Stockholm, Sweden

${ }^{2}$ Theme Inflammation and Aging, Karolinska University Hospital, Stockholm, Sweden

${ }^{3}$ Department of Geriatric medicine, Jakobsbergsgeriatriken, Stockholm, Sweden

${ }^{4}$ Department of Geriatric medicine, Sabbatsbergsgeriatriken, Stockholm, Sweden

${ }^{5}$ Department of Geriatric medicine, Dalengeriatriken Aleris Närsjukvård $\mathrm{AB}$, Stockholm, Sweden

${ }^{6}$ Department of Geriatric medicine, Capio geriatrik Löwet, Stockholm, Sweden

${ }^{7}$ Department of Geriatric medicine, Capio geriatrik Sollentuna, Stockholm, Sweden

${ }^{8}$ Department of Geriatric medicine, Capio Geriatrik Nacka AB, Nacka, Sweden

${ }^{9}$ Department of Geriatric medicine, Handengeriatriken, Aleris Närsjukvård AB, Stockholm, Sweden

${ }^{10}$ Division of Neurogeriatrics, Department of Neurobiology, Care Sciences and Society, Karolinska Institutet, Stockholm, Sweden

${ }^{11}$ R\&D unit, Stockholms Sjukhem, Stockholm, Sweden

*Contributed equally

\section{Correspondence to:}

Sara Garcia-Ptacek MD, PhD

Division of Clinical Geriatrics,

Department of Neurobiology, Care Sciences and Society,

Karolinska Institutet, NEO, Blickagången 16, 141 52, Huddinge, Stockholm

E-mail: sara.garcia-ptacek@ki.se

\section{Hong Xu, MD PhD}

Division of Clinical Geriatrics,

Department of Neurobiology, Care Sciences and Society,

Karolinska Institutet, NEO, Blickagången 16, 141 52, Huddinge, Stockholm

E-mail: hong.xu.2@,ki.se

Running Title: Temporal trends, geriatric care, COVID-19 and non-COVID patients

\section{Word counts:}

Abstract: 337; Text: 2990; References:30; Tables:2; Figures:3 
It is made available under a CC-BY-NC-ND 4.0 International license .

\section{KEY POINTS}

48 Question: Multiple previous reports in different countries and settings have shown higher case

49 fatality ratio or hospitalized case fatality ratio for COVID-19 in the first wave compared to the

50 second wave of the pandemic. However, less is known about how the COVID-19 waves

51 specifically affected the care of geriatric patients, including those with conditions other than

52 COVID. .

54 Findings: The total number of hospitalizations was 5,320 for COVID-19 and 32,243 for non55 COVID-cases. In COVID-patients, the 30-day mortality rate was highest at the beginning of the 56 first wave (29\% in March-April 2020), reached $17 \%$ at the second wave peak (November57 December) followed by $11-13 \%$ in the third wave (March-July 2021). The mortality in non58 COVID geriatric patients showed a similar trend, but of lower magnitude (5-10\%). During the 59 incidence peaks, COVID-19 hospitalizations displaced non-COVID geriatric patients.

60

Meaning: Hospital admissions and 30-day mortality after hospitalizations for COVID-19 increased in periods of high community transmission, albeit with decreasing mortality rates from wave 1 to 3 , with a possible vaccination effect in wave 3 . Thus, the healthcare system could not

64 compensate for the high community spread of COVID-19 during the pandemic peaks, which also 65 led to displacing care for non-COVID geriatric patients. These results are important for planning

66 healthcare resources in future health emergencies. 
It is made available under a CC-BY-NC-ND 4.0 International license .

\begin{abstract}
Importance: Previous reports have suggested reductions in mortality risk from COVID-19 throughout the first wave of the COVID-19 pandemic. Mortality changes later in the pandemic and pandemic effects on other types of geriatric hospitalizations are less studied.
\end{abstract}

Objectives: To describe the changes in hospitalizations and 30-day mortality in Stockholm for patients 70+ receiving inpatient geriatric care for COVID-19 and other causes.

Design: Observational study. For patients 70 or older, we present the incidence of 30-day mortality from COVID-19 in the Stockholm region, in relationship to geriatric hospitalizations and 30-day mortality after admission for COVID-19 and other causes.

Setting: Hospitalizations for patients 70+ from geriatric clinics in Stockholm, Sweden hospitalized for COVID-19 or other causes between March 2020 and July 31, 2021, were included.

Participants: The total number of geriatric hospitalizations for patients $70+$ was 5,320 for COVID-19 and 32,243 for non-COVID-19 causes, corresponding to 4,565 individual COVID-19 patients and 19,308 non-COVID-19 patients.

Exposure(s): The date of hospital admission to a geriatric clinic. Main Outcome(s) and Measure(s): 30-day mortality after admission.

Results: In patients with COVID-19, the 30-day mortality rate was highest at the beginning of the first wave (29\% in March-April 2020), decreased as the first wave subsided (7\% JulyAugust), increased again in the second wave (17\% November-December), but failed to increase as much in the third wave (11-13\% March-July 2021). In non-COVID-19 geriatric patients during the same period, the 30-day mortality presented a similar trend, but with a smaller magnitude of variation (5 to 10\%). The number of persons 70 or older testing positive for COVID-19 in Stockholm reached two peaks in 2020 (April and December), fell in January 2021 and then increased again in March-April 2021.

Conclusions and Relevance: During the first and second waves, hospital admissions and 30day mortality after geriatric hospitalization for COVID-19 increased in periods of high community transmission, although the mortality peak was lower in wave 2 than in wave 1 . The mortality for non-COVID geriatric cases was lower and more stable but also showed an increase with the pandemic peaks.

Key words: COVID-19, geriatric, hospitalizations, 30-day mortality, displacing care 


\section{INTRODUCTION}

During the first wave of the COVID-19 pandemic in Stockholm from March to July 2020, mortality for COVID-19 patients hospitalized in geriatric clinics decreased over time. ${ }^{1}$ It was unclear at the time whether this was due to improved care or to patient selection of more severe cases earlier in the pandemic due to higher community incidence and an overburdened healthcare system. Our results from that first wave included only in-hospital mortality and did not explore how care for conditions other than COVID-19 was impacted by the pandemic. Age is among the strongest risk factors for COVID-19 and the infection fatality ratio after age 70 is substantial. ${ }^{2,3}$ Here, we present data on geriatric hospitalizations for COVID-19 and other causes, including 30-day mortality from admission and compare these to the incidence of COVID-19 and 30-day mortality from COVID-19 in the Stockholm region for persons 70+. We aim to describe how COVID-19 peaks affected geriatric patients 70 and older hospitalized both for COVID-19 and for other causes in Stockholm. ${ }^{4-7}$

In previous reports, COVID-19 mortality in hospitalized patients in Sweden increased with each pandemic wave and decreased between pandemic peaks. ${ }^{8,9}$ According to the Swedish Board of Health and Welfare, 60-day mortality after admission with COVID-19 decreased from a first-wave peak in March 2020 (25\%) to a first nadir in August-September 2020 (10\%), then rose again but to lower levels as the second wave progressed to a peak in December 2020 $(20 \%)$, decreasing steadily afterwards. ${ }^{10}$ Decreasing mortality during the first pandemic wave was also observed in studies from the US, ${ }^{11}$ with subsequent increases in mortality during pandemic surges. ${ }^{12}$ A Spanish study reported that COVID-19 patients in the first wave were older, with more comorbidities and higher mortality than in the second wave. ${ }^{13}$ However, information is missing on mortality trends later in the pandemic, trends in older population and in geriatric patients with diagnoses other than COVID-19.

The aim of this study is to describe the changes over time in 30 day-mortality after admission of patients 70 years and older, hospitalized in 9 geriatric clinics in the Stockholm region from March 2020 to July 2021. We describe 30-day mortality both for patients hospitalized for COVID-19 and other causes over the three waves of the pandemic. Weekly hospitalizations for COVID-19 and other causes are presented and compared to the average weekly hospitalizations in the same geriatric clinics in 2019. These results are presented in the context of COVID-19 incidence and 30-day mortality and weekly hospitalizations from any cause in population 70 and over in the Stockholm region.

\section{METHODS}

\section{Study population}

We identified all hospitalizations of patients 70 years and older who were admitted to nine geriatric hospitals in Stockholm, Sweden, from March $6^{\text {th }}, 2020$, to July 31st, 2021. We excluded hospitalizations with a duration less than 24 hours or with an admission date after August $1^{\text {st }}, 2021$, to allow one month follow-up for mortality. A total of 5,320 hospitalizations for COVID-19 were included, together with 32,243 hospitalizations with non-COVID-19 diagnoses during the same period (Figure 1). This corresponded to 4,565 individual COVID19 patients and 19,308 non-COVID-19 patients. 


\section{Exposure and Outcome}

The study exposure was the hospital admission date (March $1^{\text {st }}, 2020$, to July $\left.31^{\text {st }}, 2021\right)$. The study outcome was 30-day mortality from admission. Patients were censored at death, or the end of follow-up (September 10th, 2021) whichever came first.

\section{COVID-19 diagnosis and covariates}

The diagnosis of COVID-19 followed clinical practice and was based on a positive reverse transcriptase-polymerase chain reaction (RT-PCR) analysis from nasopharyngeal swabs or, in case of a negative RT-PCR, typical clinical picture (including a consultation with a specialist in infectious diseases) and a CT scan with typical COVID-19 findings. All hospitalizations were included, and patients could have multiple hospitalizations. Hospitalizations for diagnoses other than COVID-19 to the same nine geriatric hospitals in Stockholm during the same period comprised the non-COVID group. We collected information on patient demographics, initial vital signs, medications, diagnoses at discharge, and 30-day mortality through the hospital electronic health records. 30-day mortality was defined from the date of admission to geriatrics.

\section{COVID-19 incidence and mortality in the population 70 years and older in Stockholm}

Information on confirmed cases with COVID-19 and mortality data in the population 70 and over in Stockholm was provided by the Swedish Board of Health and Welfare for research purposes (www.socialstyrelsen.se). Incidence data represents detected COVID-19 infections. Thirty-day mortality corresponds to deaths where COVID-19 was the main cause of death within 30 days of a positive test for persons 70 and over in the Stockholm region. Weekly hospitalizations for any cause in this population were also included as reference.

\section{Weekly hospitalizations in 2019}

For comparison, the average weekly hospitalizations registered in 2019 in the 9 geriatric clinics was presented. This was calculated by adding the total number of hospitalizations from all clinics $(30,969)$ and dividing by 52 calendar weeks resulting in an average of 596 new hospitalizations per week.

\section{Analysis}

Summary statistics are displayed as mean \pm standard deviation (SD) or median (interquartile range, IQR) or proportions.

30-day mortality rate is graphically presented in relationship to number of new admissions per week and COVID-19 incidence and mortality in the Stockholm region. Via logistic regression models, we assessed the effect of admission date on 30-day mortality, adjusted by age, sex, and medical treatment. Results were reported as odds ratios (OR) and 95\% confidence interval (CI). Mortality rates were also compared against non-COVID-19 patients admitted to the same geriatric clinics during the same period.

All analyses were performed using R (https://www.r-project.org) and Stata version 17.0 (StataCorp, College Station, TX). 


\section{Ethical statement}

The Swedish Ethical Review Authority approved the study (Dnr 2020-02146, and 202003345).

\section{RESULTS}

\section{Characteristics and treatments at admission}

Among the hospitalizations due to COVID-19, $87 \%$ (4645 hospitalizations) had positive COVID-19 RT-PCR while 675 (13\%) had a negative RT-PCR but fulfilled the clinical and radiological criteria for COVID-19. Patients hospitalized for COVID-19 had a median age of 84 (IQR 78-89) years, $53 \%$ were women and $6 \%$ of the patients had low saturation $(<90 \%)$ at admission. The median duration of hospitalization was 9 days (IQR 6-13) (Table 1). The median age of geriatric hospitalizations for other (non-COVID-19) diagnoses was higher (85 IQR 79-90), and their hospital stays were shorter (6 days: IQR 4-9).

The total number of hospitalizations in the geriatric hospitals fell sharply at the beginning of the pandemic from a pre-pandemic weekly average of 596 in 2019. After this initial drop in the first wave, geriatric hospitalizations rallied, averaging 507 hospitalizations per week but without a sustained return to pre-pandemic levels. When COVID-19 cases increased, nonCOVID-19 cases decreased accordingly (Figure 2A; Supplemental table 1).

\section{Thirty-day mortality}

Thirty-day mortality was highest at the beginning of the first wave (29\% in March-April 2020 for COVID-19; 10\% for non-COVID-19), decreased as the first wave subsided (7\% JulyAugust for COVID-19; 6\% for non-COVID-19), and increased again for COVID cases in the second wave (17\% November-December for COVID; $7 \%$ for non-COVID). Thirty-day mortality remained more stable in the third wave (11 to 13\% March-July 2021 for COVID-19; $6 \%$ non-COVID-19) (Table 1).

Figure 2B shows the relationship between weekly COVID-19 hospital admissions to the nine geriatric hospitals and 30-day mortality. Mortality is lowest when few COVID-19 patients are hospitalized. Figure 2C presents the same relationship but for other geriatric patients. The lowest mortality rates appear in the interpandemic peaks, when COVID hospitalizations were lowest and non-COVID hospitalizations were highest.

Figure 3 shows the relationship between total COVID-19 cases and deaths in the Stockholm region and COVID-19 hospitalizations and deaths in the geriatric hospitals. The number of hospitalizations and the 30-day mortality rates increased with each pandemic peak and decreased between the peaks. The 30-day mortality rate after a positive test in Stockholm and the 30-day mortality rate after admission in the geriatric hospitals followed the pandemic and hospitalization curves. The smaller increase in the third wave probably indicates a vaccination effect.

Table 2 shows 30-day mortality risk from logistic regression, adjusted by age, sex, Charlson Comorbidity Index (CCI) and treatment. Compared with patients admitted to geriatrics for COVID-19 in November-December 2020, the risk of 30-day mortality was higher (OR 1.92, 95\% CI 1.55-2.37) in March-April 2020, and lower in July August 2020 (OR 0.31, 0.15-0.66). A downward tendency appeared again in January-February 2021(OR 0.70, 0.54-0.91), MarchApril 2021 (OR 0.72, 0.55-0.94) and May-June-July (OR 0.75, 0.49-1.13) (Table 2). 
It is made available under a CC-BY-NC-ND 4.0 International license .

\section{Thirty-day mortality in non-COVID-19 hospitalizations}

Compared with hospitalizations in November-December 2020, hospitalizations in MarchApril 2020 had the highest mortality risk (OR 1.33; 95 CI 1.10-1.61), while hospitalizations from September-October 2020 (OR 0.67; 95\% CI 0.55-0.82), March-April 2021 (0.81; 95\% CI 0.67-0.99) and May-July 2021 (OR 0.82; 95\% CI 0.69-0.98) presented lower risk, after adjusting (Table 1, Figure 2).

\section{DISCUSSION}

Several important observations appear in this study of hospitalized geriatric patients in Stockholm, Sweden. First, hospital admissions fell sharply at the beginning of the pandemic and didn't reach pre-pandemic levels throughout the whole observation period. Longer hospital stays in COVID-19 patients could be one reason for this finding. The length of hospitalization for COVID-19 patients was in line with previous international reports. ${ }^{11,14} \mathrm{~A}$ reduction in elective procedures probably also contributed to the fall in admissions. The higher care burden for COVID-19 patients, together with the time required to don and doff protective equipment may have led to greater care burden and lower capacity to accept new cases. Additionally, hip and other osteoporotic fractures might have decreased in the population 70 and older due to the recommendations for this age group to avoid social contact. ${ }^{15}$ Hospital admissions further decreased during the summer months: the receding COVID-19 waves probably contributed to this reduction as did the customary reductions in available beds due to staff vacation which occur every summer.

Care seeking behaviour and the capacity of the healthcare system to detect and manage other diseases was affected during the pandemic: for example, the Swedish Stroke Register reports a decrease in the number of detected strokes in 2020 and 2021 compared to 2019. ${ }^{16}$. The Swedish registry for cognitive/dementia disorders reported a $30 \%$ reduction in diagnostic work-up. ${ }^{17}$ One US study included over 23 million emergency department (ED) visits for elderly Medicare beneficiaries, and compared hospital admission rate and changes in 30-day mortality between identical periods in 2018-19 and 2019-20. ${ }^{18}$ The drop in ED visits and increase in admission rate didn't correlate with local COVID-19 incidence. Mortality risk after ED visits also increased. The drop in ED visits, together with increased admission rate and mortality suggest that patients were avoiding seeking care, selecting for a sicker patient population in the ED. Furthermore, the lack of correlation with COVID-19 incidence suggests that patient behaviours (rather than hospital capacity) were responsible. ${ }^{18}$ Another US study found a decrease in ED visits for serious cardiovascular conditions early in the pandemic with gradual recovery (until October 2020) ${ }^{19}$. The same drop in cardiovascular visits was seen in Europe. $^{20,21}$ In contrast to the US study we saw a drop in hospitalizations in our cohort but not a complete recovery afterwards. We do not have data on ED visits so we cannot distinguish between patient care-seeking behaviours and triage in the ED. As seen in figure 2A COVID19 patients displaced other diagnoses from geriatric care. The supply of geriatric hospitalizations in our cohort was inelastic, remained relatively stable during the pandemic and was lower than in 2019.

Second, 30-day mortality rose and fell with the pandemic waves. However, the peak mortality in geriatric clinics was higher in the first than in the second wave. This effect was more evident for COVID-19 patients but appeared also in non-COVID geriatric patients. Several studies, including our previous study, have noted a decrease in mortality throughout the first 
It is made available under a CC-BY-NC-ND 4.0 International license .

wave of the pandemic ${ }^{22}{ }^{1}$. A subsequent increase was observed again during the second wave in Sweden ${ }^{9,23}$. One study included more than 30,000 COVID-19 patients (including those admitted to the ICU) hospitalized between March and December 2020 in Sweden and showed that the 60-day case fatality rate for hospitalized cases decreased in the first wave but increased again in the second wave ${ }^{9}$. This study noted that the average age and comorbidities for hospitalized patients increased in the second wave, although they adjusted for these and other factors.

COVID-19 incidence was more severely underreported in the first wave in Sweden than later in the pandemic. ${ }^{23}$ Some patients were treated in their nursing homes and never transferred to hospital, and this could have the effect of lowering the average age and comorbidities in the first wave but, interestingly, this change in average age is not present in our cohort. This may be explained by the fact that most patients admitted to inpatient geriatric hospital care lived in their own homes prior to admission. In this geriatric cohort, the proportion of patients presenting with oxygen saturation under $90 \%$ at baseline decreased from $8.9 \%$ in March-April 2020 to $2 \%$ in June, increasing again to $7.7 \%$ in December 2020. In our previous article we showed that low oxygen saturation at baseline explained some, but not all, of the temporal trend in mortality observed during the first wave. ${ }^{1}$ Triage was probably harsher in the first wave leading to a sicker patient population and higher mortality. The alpha variant arrived in Sweden in December 2020, too late to explain the increase in 30-day mortality. Improvements in treatment may also explain a part of the reduction in mortality.

In an international context, studies from Africa ${ }^{24}$, Italy ${ }^{25}$, and Germany ${ }^{26}$ showed a significant difference in COVID-mortality between the first wave and the second wave. Our temporal trend closely follows the German report, with high initial case fatal ratio, nadir in summer 2020 and subsequent increase in the second wave. In Germany, the first wave was smaller and led to fewer hospitalizations than the second, while the peaks in hospitalizations between the waves were more similar in Sweden. Despite this, the highest mortality in both studies was seen in the initial peak of the first wave $\mathrm{e}^{26}$. Another study examined raw case fatality ratio $(\mathrm{CFR})$ in 53 countries or regions and showed decreased mortality in the second wave in 43 of them, including in Sweden. ${ }^{27}$

Third, vaccinations probably changed the association between incidence and mortality in the third wave and averted the increase in 30-day mortality that had been apparent with increasing hospitalizations in the previous waves. The COVID-19 vaccination campaign began at the end of December 2020 in nursing homes and its effects on mortality were felt already in MarchApril 2021, as also seen in our cohort. ${ }^{28}$

We cannot completely explain the changes in mortality. First, it should be noted that the 30day mortality rate for COVID-19 patients reported in our study is based on a large cohort of older people in geriatric clinics in Stockholm, excluding nursing home patients treated in place, mild cases treated at home or cases treated in ICU or infectious disease wards instead of the geriatric clinics. Second, during the first wave of pandemic, the treatment and care of COVID-19 patients underwent great changes (https://www.internetmedicin.se/behandlingsoversikter/infektion/covid-19/), and these improvements are likely to be part of the reason for the decline in mortality during the first wave. In the second wave, the national guidelines for COVID-19 patients hospitalized in 
It is made available under a CC-BY-NC-ND 4.0 International license .

Sweden didn't undergo major changes. In a previous report, we have shown that the prognosis of COVID-19 for the most frail during the first wave was ominous ${ }^{29}$. It is possible that the most vulnerable and frail died during the first wave and thus contributing to lower mortality during the second wave.

We believe that due to the inelasticity of hospitalizations, increasing COVID-19 admissions during pandemic waves led to corresponding decreases in non-COVID admissions. This may have led to more stringent selection of admissions, a sicker patient population and greater overall mortality. Changes in treatment guidelines, particularly use of anticoagulants and corticosteroids led to improvement in the outcome of patients with COVID-19 ${ }^{30}$. However, except for vaccines and the third wave, these changes were implemented relatively early in the pandemic (before or during the summer of 2020) and cannot explain all the later changes in mortality. ${ }^{30}$

\section{Strengths and limitations:}

In Sweden, geriatric hospitalizations are indicated on criteria of biological (and not chronological aging). Non-frail and non-comorbid older patients may have been hospitalized in other clinics (eg. infectious diseases) and not included in our cohort. Nine out of eleven existing geriatric clinics in Stockholm participated in the study. Living situation, comorbidities and medications were obtained from electronic health records with imperfect ascertainment. Medications were considered present if they were present or prescribed within $24 \mathrm{~h}$ of hospitalization and would have included both newly prescribed medications and those removed after admission. We did not have information on vaccination, which would have been useful for assessing the decline of mortality in the third wave of the pandemic. Strengths of this study are the large geriatric cohort including nine out of eleven geriatric clinics in Stockholm treating patients with COVID-19. Also novel is the analysis of geriatric hospitalizations for other causes and the long study period including three pandemic waves over a period of 17 months.

\section{Conclusion:}

Thirty-day mortality was highest at the peak of the first wave, decreased in the inter-wave period and then increased again but to a lower peak in the second wave. The mortality increase of the third wave was probably averted by the vaccination campaign. Non-COVID mortality showed a similar trend but with lower magnitude. During COVID-19 incidence peaks, COVID-19 hospitalizations displaced non-COVID geriatric patients. Despite a massive organizational effort and the individual effort and sacrifice of health care workers, the healthcare system could not compensate for high community spread of COVID-19 during the pandemic peaks. Hospital admissions fell at the beginning of the pandemic and never returned to pre-pandemic levels, probably reflecting the greater complexity of COVID-19 patients compared to ordinary geriatric patients. The sustained fall in hospital admissions is particularly worrisome considering the backlog of cancelled and deferred care caused by the pandemic. COVID-19 disproportionally affects geriatric patients, and the broader pandemic has disrupted geriatric care. 
medRxiv preprint doi: https://doi.org/10.1101/2021.12.22.21268237; this version posted December 27, 2021. The copyright holder for this preprint (which was not certified by peer review) is the author/funder, who has granted medRxiv a license to display the preprint in perpetuity.

It is made available under a CC-BY-NC-ND 4.0 International license.

\section{ACKNOWLEDGEMENTS}

375 Sara Garcia-Ptacek has received funding from the Swedish Stroke Association, the regional 376 agreement on medical training and clinical research between the Stockholm County council 377 and the Karolinska Institutet (ALF) and FORTE (\#2017-01646). Hong Xu by StratNeuro (the 378 Strategic Research Area Neuroscience-Karolinska Institutet, Umeå University and KTH) and the Center for Innovative Medicine (CIMED). Maria Eriksdotter by the Swedish medical research council grant (\#2016-02317 and \#2020-02014) and the regional agreement on medical training and clinical research between the Stockholm County council and the Karolinska Institutet (ALF), Dorota Religa by the Swedish Research Council (\#2012-2291 and 2020-06101). The authors are grateful to the Swedish Board of Health and Welfare (Frida Broström and Henrik Nordin) for providing epidemiological data on COVID-19 in the population 70 years and older in Stockholm. The authors appreciate covidxix.org for their clear presentation of Swedish Covid-19 statistics and their help in finding relevant data for

388

\section{DECLARATION OF INTERESTS}

390 None of the authors declare any conflict of interest pertinent to the present work. 


\section{REFERENCES}

393 1. Xu H, Garcia-Ptacek S, Annetorp M, et al. Decreased Mortality Over Time During the 394 First Wave in Patients With COVID-19 in Geriatric Care: Data From the Stockholm GeroCovid Study. J 395 Am Med Dir Assoc. Aug 2021;22(8):1565-1573 e4. doi:10.1016/j.jamda.2021.06.005

$3962 . \quad$ Seoane B. A scaling approach to estimate the age-dependent COVID-19 infection 397 fatality ratio from incomplete data. PLoS One. 2021;16(2):e0246831.

398 doi:10.1371/journal.pone.0246831

$3993 . \quad$ Russell TW, Hellewell J, Jarvis $\mathrm{Cl}$, et al. Estimating the infection and case fatality ratio 400 for coronavirus disease (COVID-19) using age-adjusted data from the outbreak on the Diamond 401 Princess cruise ship, February 2020. Euro Surveill. Mar 2020;25(12)doi:10.2807/1560-

402 7917.ES.2020.25.12.2000256

4034 4. Horby P, Lim WS, Emberson JR, et al. Dexamethasone in Hospitalized Patients with 404 Covid-19 - Preliminary Report. The New England journal of medicine. Jul 17

405 2020;doi:10.1056/NEJMoa2021436

$4065 . \quad$ Beigel JH, Tomashek KM, Dodd LE, et al. Remdesivir for the Treatment of Covid-19 -

407 Final Report. The New England journal of medicine. Oct 8 2020;doi:10.1056/NEJMoa2007764

408 6. Paolisso P, Bergamaschi L, D'Angelo EC, et al. Preliminary Experience With Low

409 Molecular Weight Heparin Strategy in COVID-19 Patients. Frontiers in pharmacology. 2020;11:1124. 410 doi:10.3389/fphar.2020.01124

411 7. Wang Y, Zhang D, Du G, et al. Remdesivir in adults with severe COVID-19: a

412 randomised, double-blind, placebo-controlled, multicentre trial. Lancet (London, England). May 16

413 2020;395(10236):1569-1578. doi:10.1016/s0140-6736(20)31022-9

414 8. Strålin K, Wahlström E, Walther S, et al. Mortality trends among hospitalised COVID-19

415 patients in Sweden: A nationwide observational cohort study. Lancet Reg Health Eur. May

416 2021;4:100054. doi:10.1016/j.lanepe.2021.100054

$417 \quad 9 . \quad$ Strålin K, Wahlström E, Walther S, et al. Second wave mortality among patients

418 hospitalised for COVID-19 in Sweden: a nationwide observational cohort study. medRxiv.

419 2021:2021.03.29.21254557. doi:10.1101/2021.03.29.21254557

$420 \quad 10 . \quad$ Welfare SBoHa. Healthcare and Covid. 2021. Accessed 2021-09-29.

421 https://www.socialstyrelsen.se/statistik-och-data/statistik/statistik-om-covid-19/statistik-om-

422 slutenvard-av-patienter-med-covid-19/

$423 \quad 11 . \quad$ Nguyen JL, Benigno M, Malhotra D, et al. Hospitalization and mortality trends among

424 patients with confirmed COVID-19 in the United States, April through August 2020. Journal of Public

425 Health Research. 10/28 2021;doi:10.4081/jphr.2021.2244

$42612 . \quad$ Moon RC, Mackey RH, Cao Z, et al. Is COVID-19 Less Deadly Now? -- Trends of In-

427 Hospital Mortality Among Hospitalized COVID-19 Patients in the United States. Clin Infect Dis. Sep 17

428 2021;doi:10.1093/cid/ciab830

429 13. Aznar-Gimeno R, Pano-Pardo JR, Esteban LM, et al. Changes in severity, mortality, and

430 virus genome among a Spanish cohort of patients hospitalized with SARS-CoV-2. Sci Rep. Sep 22

431 2021;11(1):18844. doi:10.1038/s41598-021-98308-x

$43214 . \quad$ Vekaria B, Overton C, Wisniowski A, et al. Hospital length of stay for COVID-19 patients:

433 Data-driven methods for forward planning. BMC Infect Dis. Jul 22 2021;21(1):700.

434 doi:10.1186/s12879-021-06371-6

$43515 . \quad$ Rydberg EM, Möller M, Ekelund J, Wolf O, Wennergren D. Does the Covid-19

436 pandemic affect ankle fracture incidence? Moderate decrease in Sweden. Acta Orthop. Aug

437 2021;92(4):381-384. doi:10.1080/17453674.2021.1907517

$438 \quad 16 . \quad$ Register TSS. Covid-19 report Stroke. 2021:4-5. Accessed 2021-09-29.

439 https://www.riksstroke.org/sve/forskning-statistik-och-verksamhetsutveckling/rapporter/ovriga-

$440 \quad$ rapporter-2/

$44117 . \quad$ SveDem Annual report 2021. . https://wwwucruuse/svedem/om-svedem/arsrapporter.

4422021. 
It is made available under a CC-BY-NC-ND 4.0 International license .

443

444

445

446

447

448

449

450

451

452

453

454

455

456

457

458

459

460

461

462

463

464

465

466

467

468

469

470

471

472

473

474

475

476

477

478

479

480

481

482

18. Smulowitz PB, O'Malley AJ, Khidir H, Zaborski L, McWilliams JM, Landon BE. National Trends In ED Visits, Hospital Admissions, And Mortality For Medicare Patients During The COVID-19 Pandemic. Health Affairs. 2021/09/01 2021;40(9):1457-1464. doi:10.1377/hlthaff.2021.00561 19. Pines JM, Zocchi MS, Black BS, et al. The effect of the COVID-19 pandemic on emergency department visits for serious cardiovascular conditions. Am J Emerg Med. Sep 2021;47:42-51. doi:10.1016/j.ajem.2021.03.004

20. De Rosa S, Spaccarotella C, Basso C, et al. Reduction of hospitalizations for myocardial infarction in Italy in the COVID-19 era. Eur Heart J. Jun 7 2020;41(22):2083-2088. doi:10.1093/eurheartj/ehaa409

21. Sokolski M, Gajewski P, Zymlinski R, et al. Impact of Coronavirus Disease 2019 (COVID19) Outbreak on Acute Admissions at the Emergency and Cardiology Departments Across Europe. Am $J$ Med. Apr 2021;134(4):482-489. doi:10.1016/j.amjmed.2020.08.043

22. Strålin K, Wahlström E, Walther S, et al. Mortality trends among hospitalised COVID-19 patients in Sweden: A nationwide observational cohort study. The Lancet Regional Health - Europe. 2021;4doi:10.1016/j.lanepe.2021.100054

23. Statistics on hospitalizations of patients with Covid-19 (2021).

24. Salyer SJ, Maeda J, Sembuche S, et al. The first and second waves of the COVID-19

pandemic in Africa: a cross-sectional study. Lancet (London, England). Apr 3 2021;397(10281):12651275. doi:10.1016/s0140-6736(21)00632-2

25. Dorrucci M, Minelli G, Boros S, et al. Excess Mortality in Italy During the COVID-19 Pandemic: Assessing the Differences Between the First and the Second Wave, Year 2020. Frontiers in public health. 2021;9:669209. doi:10.3389/fpubh.2021.669209

26. Gessler N, Gunawardene MA, Wohlmuth P, et al. Clinical outcome, risk assessment, and seasonal variation in hospitalized COVID-19 patients-Results from the CORONA Germany study. PloS one. 2021;16(6):e0252867. doi:10.1371/journal.pone.0252867

27. Fan G, Yang Z, Lin Q, Zhao S, Yang L, He D. Decreased Case Fatality Rate of COVID-19 in the Second Wave: A study in 53 countries or regions. Transboundary and emerging diseases. Mar 2021;68(2):213-215. doi:10.1111/tbed.13819

28. Sweden PHAo. Vaccination coverage and reported cases (Vaccinationstäckning och rapporterade sjukdomsfall). 2021. 2021-05-20. Accessed 2021-11-08.

https://www.folkhalsomyndigheten.se/folkhalsorapportering-statistik/statistikdatabaser-ochvisualisering/vaccinationsstatistik/statistik-for-vaccination-mot-covid-19/uppfoljning-avvaccination/vaccinationstackning-och-rapporterade-sjukdomsfall/

$29 . \quad$ Hägg S, Jylhävä J, Wang Y, et al. Age, Frailty, and Comorbidity as Prognostic Factors for Short-Term Outcomes in Patients With Coronavirus Disease 2019 in Geriatric Care. J Am Med Dir Assoc. Nov 2020;21(11):1555-1559.e2. doi:10.1016/j.jamda.2020.08.014

30. "Swedish Society of Infectious disease specialists SHsaSfCM. National care program for suspected or confirmed COVID-19 (Nationellt vårdprogram för misstänkt och bekräftad covid-19). 2021:28. Accessed 2021-11-23. https://infektion.net/nationellt-vardprogram-covid19/\# 
medRxiv preprint doi: https://doi.org/10.1101/2021.12.22.21268237; this version posted December 27, 2021. The copyright holder for this preprint (which was not certified by peer review) is the author/funder, who has granted medRxiv a license to display the preprint in perpetuity.

It is made available under a CC-BY-NC-ND 4.0 International license .

Table 1. Hospitalizations for COVID-19 and other causes in patients 70 and over in 484 geriatric clinics

\begin{tabular}{|c|c|c|c|c|c|c|c|c|c|}
\hline & $\begin{array}{l}2020- \\
2021\end{array}$ & 2020 & 2020 & 2020 & 2020 & 2020 & 2021 & 2021 & 2021 \\
\hline & Overall & Mar-Apr & $\begin{array}{l}\text { May- } \\
\text { June }\end{array}$ & July-Aug & Sep-Oct & Nov-Dec & Jan-Feb & Mar-Apr & $\begin{array}{l}\text { May- } \\
\text { June- } \\
\text { July }\end{array}$ \\
\hline \multicolumn{10}{|l|}{ COVID-19 } \\
\hline $\mathbf{N}$ & 5320 & 990 & 813 & 117 & 118 & 1329 & 838 & 870 & 245 \\
\hline Age, year & $\begin{array}{l}84.0 \\
(78.0 \\
89.0)\end{array}$ & $\begin{array}{l}84.5 \\
(79.0 \\
90.0)\end{array}$ & $\begin{array}{l}85.0 \\
(79.0 \\
91.0)\end{array}$ & $\begin{array}{l}86.0 \\
(81.0 \\
90.0)\end{array}$ & $\begin{array}{l}85.5 \\
(81.0 \\
91.0)\end{array}$ & $\begin{array}{l}84.0 \\
(79.0 \\
89.0)\end{array}$ & $\begin{array}{l}83.0 \\
(78.0 \\
89.0)\end{array}$ & $\begin{array}{l}81.0 \\
(76.0, \\
86.0)\end{array}$ & $\begin{array}{l}81.0 \\
(75.0 \\
88.0)\end{array}$ \\
\hline Women & $\begin{array}{l}2822 \\
(53.0 \%)\end{array}$ & $\begin{array}{l}535 \\
(54.0 \%)\end{array}$ & $\begin{array}{l}442 \\
(54.4 \%)\end{array}$ & $\begin{array}{l}63 \\
(53.8 \%)\end{array}$ & $\begin{array}{l}70 \\
(59.3 \%)\end{array}$ & $\begin{array}{l}723 \\
(54.4 \%)\end{array}$ & $\begin{array}{l}429 \\
(51.2 \%)\end{array}$ & $\begin{array}{l}436 \\
(50.1 \%)\end{array}$ & $\begin{array}{l}124 \\
(50.6 \%)\end{array}$ \\
\hline $\mathrm{CCl}$ & $\begin{array}{l}2.0(0.0, \\
3.0)\end{array}$ & $\begin{array}{l}2.0(0.0, \\
3.0)\end{array}$ & $\begin{array}{l}2.0(0.0, \\
3.0)\end{array}$ & $\begin{array}{l}1.0(0.0, \\
3.0)\end{array}$ & $\begin{array}{l}1.0(0.0, \\
3.0)\end{array}$ & $\begin{array}{l}2.0(0.0, \\
3.0)\end{array}$ & $\begin{array}{l}2.0(0.0, \\
3.0)\end{array}$ & $\begin{array}{l}2.0(0.0, \\
3.0)\end{array}$ & $\begin{array}{l}2.0(0.0, \\
3.0)\end{array}$ \\
\hline Hypertension & $\begin{array}{l}1777 \\
(33.4 \%)\end{array}$ & $\begin{array}{l}380 \\
(38.4 \%)\end{array}$ & $\begin{array}{l}310 \\
(38.1 \%)\end{array}$ & $\begin{array}{l}25 \\
(21.4 \%)\end{array}$ & $\begin{array}{l}43 \\
(36.4 \%)\end{array}$ & $\begin{array}{l}383 \\
(28.8 \%)\end{array}$ & $\begin{array}{l}268 \\
(32.0 \%)\end{array}$ & $\begin{array}{l}306 \\
(35.2 \%)\end{array}$ & $\begin{array}{l}62 \\
(25.3 \%)\end{array}$ \\
\hline Diabetes & $\begin{array}{l}2014 \\
(37.9 \%)\end{array}$ & $\begin{array}{l}344 \\
(34.7 \%)\end{array}$ & $\begin{array}{l}287 \\
(35.3 \%)\end{array}$ & $\begin{array}{l}33 \\
(28.2 \%)\end{array}$ & $\begin{array}{l}32 \\
(27.1 \%)\end{array}$ & $\begin{array}{l}510 \\
(38.4 \%)\end{array}$ & $\begin{array}{l}331 \\
(39.5 \%)\end{array}$ & $\begin{array}{l}367 \\
(42.2 \%)\end{array}$ & $\begin{array}{l}110 \\
(44.9 \%)\end{array}$ \\
\hline $\begin{array}{l}\text { Chronic heart } \\
\text { failure }\end{array}$ & $\begin{array}{l}761 \\
(14.3 \%)\end{array}$ & $\begin{array}{l}179 \\
(18.1 \%)\end{array}$ & $\begin{array}{l}152 \\
(18.7 \%)\end{array}$ & $\begin{array}{l}11 \\
(9.4 \%)\end{array}$ & $\begin{array}{l}21 \\
(17.8 \%)\end{array}$ & $\begin{array}{l}176 \\
(13.2 \%)\end{array}$ & $\begin{array}{l}115 \\
(13.7 \%)\end{array}$ & $\begin{array}{l}85 \\
(9.8 \%)\end{array}$ & $\begin{array}{l}22 \\
(9.0 \%)\end{array}$ \\
\hline $\begin{array}{l}\text { Myocardial } \\
\text { Infarction }\end{array}$ & $\begin{array}{l}233 \\
(4.4 \%)\end{array}$ & $\begin{array}{l}43 \\
(4.3 \%)\end{array}$ & $\begin{array}{l}31 \\
(3.8 \%)\end{array}$ & $1(0.9 \%)$ & $4(3.4 \%)$ & $\begin{array}{l}57 \\
(4.3 \%)\end{array}$ & $\begin{array}{l}39 \\
(4.7 \%)\end{array}$ & $\begin{array}{l}44 \\
(5.1 \%)\end{array}$ & $\begin{array}{l}14 \\
(5.7 \%)\end{array}$ \\
\hline $\begin{array}{l}\text { Chronical } \\
\text { pulmonary } \\
\text { disease }\end{array}$ & $\begin{array}{l}709 \\
(13.3 \%)\end{array}$ & $\begin{array}{l}148 \\
(14.9 \%)\end{array}$ & $\begin{array}{l}108 \\
(13.3 \%)\end{array}$ & $9(7.7 \%)$ & $\begin{array}{l}20 \\
(16.9 \%)\end{array}$ & $\begin{array}{l}185 \\
(13.9 \%)\end{array}$ & $\begin{array}{l}114 \\
(13.6 \%)\end{array}$ & $\begin{array}{l}106 \\
(12.2 \%)\end{array}$ & $\begin{array}{l}19 \\
(7.8 \%)\end{array}$ \\
\hline Asthma & $\begin{array}{l}185 \\
(3.5 \%)\end{array}$ & $\begin{array}{l}36 \\
(3.6 \%)\end{array}$ & $\begin{array}{l}24 \\
(3.0 \%)\end{array}$ & $3(2.6 \%)$ & $8(6.8 \%)$ & $\begin{array}{l}41 \\
(3.1 \%)\end{array}$ & $\begin{array}{l}28 \\
(3.3 \%)\end{array}$ & $\begin{array}{l}39 \\
(4.5 \%)\end{array}$ & $6(2.4 \%)$ \\
\hline Cancer & $\begin{array}{l}331 \\
(6.2 \%)\end{array}$ & $\begin{array}{l}74 \\
(7.5 \%)\end{array}$ & $\begin{array}{l}49 \\
(6.0 \%)\end{array}$ & $\begin{array}{l}16 \\
(13.7 \%)\end{array}$ & $\begin{array}{l}10 \\
(8.5 \%)\end{array}$ & $\begin{array}{l}84 \\
(6.3 \%)\end{array}$ & $\begin{array}{l}41 \\
(4.9 \%)\end{array}$ & $\begin{array}{l}42 \\
(4.8 \%)\end{array}$ & $\begin{array}{l}15 \\
(6.1 \%)\end{array}$ \\
\hline Stroke & $\begin{array}{l}307 \\
(5.8 \%)\end{array}$ & $\begin{array}{l}66 \\
(6.7 \%)\end{array}$ & $\begin{array}{l}58 \\
(7.1 \%)\end{array}$ & $4(3.4 \%)$ & $9(7.6 \%)$ & $\begin{array}{l}79 \\
(5.9 \%)\end{array}$ & $\begin{array}{l}38 \\
(4.5 \%)\end{array}$ & $\begin{array}{l}39 \\
(4.5 \%)\end{array}$ & $\begin{array}{l}14 \\
(5.7 \%)\end{array}$ \\
\hline $\begin{array}{l}\text { Atrial } \\
\text { fibrillation }\end{array}$ & $\begin{array}{l}1061 \\
(19.9 \%)\end{array}$ & $\begin{array}{l}217 \\
(21.9 \%)\end{array}$ & $\begin{array}{l}195 \\
(24.0 \%)\end{array}$ & $\begin{array}{l}25 \\
(21.4 \%)\end{array}$ & $\begin{array}{l}26 \\
(22.0 \%)\end{array}$ & $\begin{array}{l}273 \\
(20.5 \%)\end{array}$ & $\begin{array}{l}151 \\
(18.0 \%)\end{array}$ & $\begin{array}{l}139 \\
(16.0 \%)\end{array}$ & $\begin{array}{l}35 \\
(14.3 \%)\end{array}$ \\
\hline Initial S02<90\% & $\begin{array}{l}342 \\
(6.4 \%)\end{array}$ & $\begin{array}{l}89 \\
(9.0 \%)\end{array}$ & $\begin{array}{l}39 \\
(4.8 \%)\end{array}$ & $3(2.6 \%)$ & $7(5.9 \%)$ & $\begin{array}{l}99 \\
(7.4 \%)\end{array}$ & $\begin{array}{l}50 \\
(6.0 \%)\end{array}$ & $\begin{array}{l}42 \\
(4.8 \%)\end{array}$ & $\begin{array}{l}13 \\
(5.3 \%)\end{array}$ \\
\hline ACEI & $\begin{array}{l}1229 \\
(23.1 \%)\end{array}$ & $\begin{array}{l}246 \\
(24.8 \%)\end{array}$ & $\begin{array}{l}198 \\
(24.4 \%)\end{array}$ & $\begin{array}{l}21 \\
(17.9 \%)\end{array}$ & $\begin{array}{l}24 \\
(20.3 \%)\end{array}$ & $\begin{array}{l}276 \\
(20.8 \%)\end{array}$ & $\begin{array}{l}204 \\
(24.3 \%)\end{array}$ & $\begin{array}{l}190 \\
(21.8 \%)\end{array}$ & $\begin{array}{l}70 \\
(28.6 \%)\end{array}$ \\
\hline ARB & $\begin{array}{l}1462 \\
(27.5 \%)\end{array}$ & $\begin{array}{l}251 \\
(25.4 \%)\end{array}$ & $\begin{array}{l}209 \\
(25.7 \%)\end{array}$ & $\begin{array}{l}32 \\
(27.4 \%)\end{array}$ & $\begin{array}{l}40 \\
(33.9 \%)\end{array}$ & $\begin{array}{l}378 \\
(28.4 \%)\end{array}$ & $\begin{array}{l}243 \\
(29.0 \%)\end{array}$ & $\begin{array}{l}248 \\
(28.5 \%)\end{array}$ & $\begin{array}{l}61 \\
(24.9 \%)\end{array}$ \\
\hline$\beta$-blocker & $\begin{array}{l}2745 \\
(51.6 \%)\end{array}$ & $\begin{array}{l}531 \\
(53.6 \%)\end{array}$ & $\begin{array}{l}419 \\
(51.5 \%)\end{array}$ & $\begin{array}{l}65 \\
(55.6 \%)\end{array}$ & $\begin{array}{l}54 \\
(45.8 \%)\end{array}$ & $\begin{array}{l}681 \\
(51.2 \%)\end{array}$ & $\begin{array}{l}436 \\
(52.0 \%)\end{array}$ & $\begin{array}{l}430 \\
(49.4 \%)\end{array}$ & $\begin{array}{l}129 \\
(52.7 \%)\end{array}$ \\
\hline CCB & $\begin{array}{l}1621 \\
(30.5 \%)\end{array}$ & $\begin{array}{l}295 \\
(29.8 \%)\end{array}$ & $\begin{array}{l}237 \\
(29.2 \%)\end{array}$ & $\begin{array}{l}34 \\
(29.1 \%)\end{array}$ & $\begin{array}{l}24 \\
(20.3 \%)\end{array}$ & $\begin{array}{l}412 \\
(31.0 \%)\end{array}$ & $\begin{array}{l}255 \\
(30.4 \%)\end{array}$ & $\begin{array}{l}286 \\
(32.9 \%)\end{array}$ & $\begin{array}{l}78 \\
(31.8 \%)\end{array}$ \\
\hline Diuretics & $\begin{array}{l}2819 \\
(53.0 \%)\end{array}$ & $\begin{array}{l}563 \\
(56.9 \%)\end{array}$ & $\begin{array}{l}449 \\
(55.2 \%)\end{array}$ & $\begin{array}{l}66 \\
(56.4 \%)\end{array}$ & $\begin{array}{l}74 \\
(62.7 \%)\end{array}$ & $\begin{array}{l}672 \\
(50.6 \%)\end{array}$ & $\begin{array}{l}453 \\
(54.1 \%)\end{array}$ & $\begin{array}{l}410 \\
(47.1 \%)\end{array}$ & $\begin{array}{l}132 \\
(53.9 \%)\end{array}$ \\
\hline Statins & $\begin{array}{l}2148 \\
(40.4 \%)\end{array}$ & $\begin{array}{l}380 \\
(38.4 \%)\end{array}$ & $\begin{array}{l}309 \\
(38.0 \%)\end{array}$ & $\begin{array}{l}40 \\
(34.2 \%)\end{array}$ & $\begin{array}{l}48 \\
(40.7 \%)\end{array}$ & $\begin{array}{l}548 \\
(41.2 \%)\end{array}$ & $\begin{array}{l}354 \\
(42.2 \%)\end{array}$ & $\begin{array}{l}380 \\
(43.7 \%)\end{array}$ & $\begin{array}{l}89 \\
(36.3 \%)\end{array}$ \\
\hline Warfarin & $\begin{array}{l}388 \\
(7.3 \%)\end{array}$ & $\begin{array}{l}85 \\
(8.6 \%)\end{array}$ & $\begin{array}{l}61 \\
(7.5 \%)\end{array}$ & $\begin{array}{l}15 \\
(12.8 \%)\end{array}$ & $7(5.9 \%)$ & $\begin{array}{l}93 \\
(7.0 \%)\end{array}$ & $\begin{array}{l}62 \\
(7.4 \%)\end{array}$ & $\begin{array}{l}48 \\
(5.5 \%)\end{array}$ & $\begin{array}{l}17 \\
(6.9 \%)\end{array}$ \\
\hline LMWH & $\begin{array}{l}2732 \\
(51.4 \%)\end{array}$ & $\begin{array}{l}410 \\
(41.4 \%)\end{array}$ & $\begin{array}{l}427 \\
(52.5 \%)\end{array}$ & $\begin{array}{l}99 \\
(33.3 \%)\end{array}$ & $\begin{array}{l}59 \\
(50.0 \%)\end{array}$ & $\begin{array}{l}772 \\
(58.1 \%)\end{array}$ & $\begin{array}{l}417 \\
(49.8 \%)\end{array}$ & $\begin{array}{l}509 \\
(58.5 \%)\end{array}$ & $\begin{array}{l}99 \\
(40.4 \%)\end{array}$ \\
\hline
\end{tabular}


medRxiv preprint doi: https://doi.org/10.1101/2021.12.22.21268237; this version posted December 27, 2021. The copyright holder for this preprint (which was not certified by peer review) is the author/funder, who has granted medRxiv a license to display the preprint in perpetuity.

It is made available under a CC-BY-NC-ND 4.0 International license .

\begin{tabular}{|c|c|c|c|c|c|c|c|c|c|}
\hline NOAC & $\begin{array}{l}1745 \\
(32.8 \%)\end{array}$ & $\begin{array}{l}262 \\
(26.5 \%)\end{array}$ & $\begin{array}{l}285 \\
(35.1 \%)\end{array}$ & $\begin{array}{l}41 \\
(35.0 \%)\end{array}$ & $\begin{array}{l}34 \\
(28.8 \%)\end{array}$ & $\begin{array}{l}429 \\
(32.3 \%)\end{array}$ & $\begin{array}{l}315 \\
(37.6 \%)\end{array}$ & $\begin{array}{l}287 \\
(33.0 \%)\end{array}$ & $\begin{array}{l}92 \\
(37.6 \%)\end{array}$ \\
\hline Glucocorticoids & $\begin{array}{l}1492 \\
(28.0 \%)\end{array}$ & $\begin{array}{l}151 \\
(15.3 \%)\end{array}$ & $\begin{array}{l}148 \\
(18.2 \%)\end{array}$ & $\begin{array}{l}23 \\
(19.7 \%)\end{array}$ & $\begin{array}{l}31 \\
(26.3 \%)\end{array}$ & $\begin{array}{l}665 \\
(35.0 \%)\end{array}$ & $\begin{array}{l}250 \\
(29.8 \%)\end{array}$ & $\begin{array}{l}338 \\
(38.9 \%)\end{array}$ & $\begin{array}{l}86 \\
(35.1 \%)\end{array}$ \\
\hline Antibiotics & $\begin{array}{l}1798 \\
(33.8 \%)\end{array}$ & $\begin{array}{l}369 \\
(37.3 \%)\end{array}$ & $\begin{array}{l}252 \\
(31.0 \%)\end{array}$ & $\begin{array}{l}41 \\
(35.0 \%)\end{array}$ & $\begin{array}{l}41 \\
(34.7 \%)\end{array}$ & $\begin{array}{l}426 \\
(32.1 \%)\end{array}$ & $\begin{array}{l}280 \\
(33.4 \%)\end{array}$ & $\begin{array}{l}288 \\
(33.1 \%)\end{array}$ & $\begin{array}{l}101 \\
(41.2 \%)\end{array}$ \\
\hline $\begin{array}{l}\text { Days of } \\
\text { hospitalization }\end{array}$ & $\begin{array}{l}9.0(6.0, \\
13.0)\end{array}$ & $\begin{array}{l}9.0(6.0, \\
14.0)\end{array}$ & $\begin{array}{l}9.0(6.0, \\
14.0)\end{array}$ & $\begin{array}{l}9.0(6.0 \\
13.0)\end{array}$ & $\begin{array}{l}11.0 \\
(8.0, \\
19.0)\end{array}$ & $\begin{array}{l}9.0(6.0, \\
14.0)\end{array}$ & $\begin{array}{l}8.0(6.0, \\
12.0)\end{array}$ & $\begin{array}{l}7.0(5.0, \\
11.0)\end{array}$ & $\begin{array}{l}8.0(5.0, \\
10.0)\end{array}$ \\
\hline $\begin{array}{l}\text { 30-day } \\
\text { mortality }\end{array}$ & $\begin{array}{l}910 \\
(17.1 \%)\end{array}$ & $\begin{array}{l}282 \\
(28.5 \%)\end{array}$ & $\begin{array}{l}134 \\
(16.5 \%)\end{array}$ & $8(6.8 \%)$ & $\begin{array}{l}21 \\
(17.8 \%)\end{array}$ & $\begin{array}{l}228 \\
(17.2 \%)\end{array}$ & $\begin{array}{l}106 \\
(12.6 \%)\end{array}$ & $\begin{array}{l}99 \\
(11.4 \%)\end{array}$ & $\begin{array}{l}32 \\
(13.1 \%)\end{array}$ \\
\hline \multicolumn{10}{|l|}{ Non-COVID } \\
\hline $\mathbf{N}$ & 32243 & 3177 & 3198 & 4191 & 4736 & 2770 & 3217 & 4028 & 6926 \\
\hline Age, year & $\begin{array}{l}85.0 \\
(79.0 \\
90.0)\end{array}$ & $\begin{array}{l}86.0 \\
(80.0 \\
91.0)\end{array}$ & $\begin{array}{l}86.0 \\
(80.0 \\
91.0)\end{array}$ & $\begin{array}{l}85.0 \\
(79.0 \\
90.0)\end{array}$ & $\begin{array}{l}85.0 \\
(79.0 \\
90.0)\end{array}$ & $\begin{array}{l}85.0 \\
(80.0 \\
90.0)\end{array}$ & $\begin{array}{l}85.0 \\
(79.0 \\
90.0)\end{array}$ & $\begin{array}{l}85.0 \\
(79.0 \\
90.0)\end{array}$ & $\begin{array}{l}85.0 \\
(79.0 \\
90.0)\end{array}$ \\
\hline Women & $\begin{array}{l}19336 \\
(60.0 \%)\end{array}$ & $\begin{array}{l}1895 \\
(59.6 \%)\end{array}$ & $\begin{array}{l}1900 \\
(59.4 \%)\end{array}$ & $\begin{array}{l}2574 \\
(61.4 \%)\end{array}$ & $\begin{array}{l}2822 \\
(59.6 \%)\end{array}$ & $\begin{array}{l}1635 \\
(59.0 \%)\end{array}$ & $\begin{array}{l}1907 \\
(59.3 \%)\end{array}$ & $\begin{array}{l}2429 \\
(60.3 \%)\end{array}$ & $\begin{array}{l}4174 \\
(60.3 \%)\end{array}$ \\
\hline $\mathrm{CCl}$ & $\begin{array}{l}1.0(0.0, \\
3.0)\end{array}$ & $\begin{array}{l}2.0(0.0, \\
3.0)\end{array}$ & $\begin{array}{l}1.0(0.0, \\
3.0)\end{array}$ & $\begin{array}{l}1.0(0.0, \\
3.0)\end{array}$ & $\begin{array}{l}1.0(0.0, \\
3.0)\end{array}$ & $\begin{array}{l}1.0(0.0, \\
3.0)\end{array}$ & $\begin{array}{l}1.0(0.0, \\
3.0)\end{array}$ & $\begin{array}{l}1.0(0.0, \\
3.0)\end{array}$ & $\begin{array}{l}1.0(0.0, \\
3.0)\end{array}$ \\
\hline Hypertension & $\begin{array}{l}9804 \\
(30.4 \%)\end{array}$ & $\begin{array}{l}1150 \\
(36.2 \%)\end{array}$ & $\begin{array}{l}1050 \\
(32.8 \%)\end{array}$ & $\begin{array}{l}1305 \\
(31.1 \%)\end{array}$ & $\begin{array}{l}1388 \\
(29.3 \%)\end{array}$ & $\begin{array}{l}817 \\
(29.5 \%)\end{array}$ & $\begin{array}{l}930 \\
(28.9 \%)\end{array}$ & $\begin{array}{l}1138 \\
(28.3 \%)\end{array}$ & $\begin{array}{l}2026 \\
(29.3 \%)\end{array}$ \\
\hline Diabetes & $\begin{array}{l}9080 \\
(28.2 \%)\end{array}$ & $\begin{array}{l}908 \\
(28.6 \%)\end{array}$ & $\begin{array}{l}844 \\
(26.4 \%)\end{array}$ & $\begin{array}{l}1174 \\
(28.0 \%)\end{array}$ & $\begin{array}{l}1360 \\
(28.7 \%)\end{array}$ & $\begin{array}{l}769 \\
(27.8 \%)\end{array}$ & $\begin{array}{l}887 \\
(27.6 \%)\end{array}$ & $\begin{array}{l}1147 \\
(28.5 \%)\end{array}$ & $\begin{array}{l}1991 \\
(28.7 \%)\end{array}$ \\
\hline $\begin{array}{l}\text { Chronic heart } \\
\text { failure }\end{array}$ & $\begin{array}{l}5001 \\
(15.5 \%)\end{array}$ & $\begin{array}{l}668 \\
(21.0 \%)\end{array}$ & $\begin{array}{l}541 \\
(16.9 \%)\end{array}$ & $\begin{array}{l}627 \\
(15.0 \%)\end{array}$ & $\begin{array}{l}680 \\
(14.4 \%)\end{array}$ & $\begin{array}{l}430 \\
(15.5 \%)\end{array}$ & $\begin{array}{l}480 \\
(14.9 \%)\end{array}$ & $\begin{array}{l}622 \\
(15.4 \%)\end{array}$ & $\begin{array}{l}953 \\
(13.8 \%)\end{array}$ \\
\hline $\begin{array}{l}\text { Myocardial } \\
\text { Infarction }\end{array}$ & $\begin{array}{l}1206 \\
(3.7 \%)\end{array}$ & $\begin{array}{l}160 \\
(5.0 \%)\end{array}$ & $\begin{array}{l}123 \\
(3.8 \%)\end{array}$ & $\begin{array}{l}163 \\
(3.9 \%)\end{array}$ & $\begin{array}{l}162 \\
(3.4 \%)\end{array}$ & $\begin{array}{l}102 \\
(3.7 \%)\end{array}$ & $\begin{array}{l}103 \\
(3.2 \%)\end{array}$ & $\begin{array}{l}140 \\
(3.5 \%)\end{array}$ & $\begin{array}{l}253 \\
(3.7 \%)\end{array}$ \\
\hline $\begin{array}{l}\text { Chronical } \\
\text { pulmonary } \\
\text { disease }\end{array}$ & $\begin{array}{l}3189 \\
(9.9 \%)\end{array}$ & $\begin{array}{l}447 \\
(14.1 \%)\end{array}$ & $\begin{array}{l}379 \\
(11.9 \%)\end{array}$ & $\begin{array}{l}417 \\
(9.9 \%)\end{array}$ & $\begin{array}{l}446 \\
(9.4 \%)\end{array}$ & $\begin{array}{l}225 \\
(8.1 \%)\end{array}$ & $\begin{array}{l}313 \\
(9.7 \%)\end{array}$ & $\begin{array}{l}345 \\
(8.6 \%)\end{array}$ & $\begin{array}{l}617 \\
(8.9 \%)\end{array}$ \\
\hline Asthma & $\begin{array}{l}538 \\
(1.7 \%)\end{array}$ & $\begin{array}{l}76 \\
(2.4 \%)\end{array}$ & $\begin{array}{l}60 \\
(1.9 \%)\end{array}$ & $\begin{array}{l}56 \\
(1.3 \%)\end{array}$ & $\begin{array}{l}74 \\
(1.6 \%)\end{array}$ & $\begin{array}{l}46 \\
(1.7 \%)\end{array}$ & $\begin{array}{l}48 \\
(1.5 \%)\end{array}$ & $\begin{array}{l}70 \\
(1.7 \%)\end{array}$ & $\begin{array}{l}108 \\
(1.6 \%)\end{array}$ \\
\hline Cancer & $\begin{array}{l}2173 \\
(6.7 \%)\end{array}$ & $\begin{array}{l}266 \\
(8.4 \%)\end{array}$ & $\begin{array}{l}246 \\
(7.7 \%)\end{array}$ & $\begin{array}{l}275 \\
(6.6 \%)\end{array}$ & $\begin{array}{l}289 \\
(6.1 \%)\end{array}$ & $\begin{array}{l}186 \\
(6.7 \%)\end{array}$ & $\begin{array}{l}219 \\
(6.8 \%)\end{array}$ & $\begin{array}{l}266 \\
(6.6 \%)\end{array}$ & $\begin{array}{l}426 \\
(6.2 \%)\end{array}$ \\
\hline Stroke & $\begin{array}{l}2254 \\
(7.0 \%)\end{array}$ & $\begin{array}{l}257 \\
(8.1 \%)\end{array}$ & $\begin{array}{l}289 \\
(9.0 \%)\end{array}$ & $\begin{array}{l}316 \\
(7.5 \%)\end{array}$ & $\begin{array}{l}327 \\
(6.9 \%)\end{array}$ & $\begin{array}{l}188 \\
(6.8 \%)\end{array}$ & $\begin{array}{l}224 \\
(7.0 \%)\end{array}$ & $\begin{array}{l}282 \\
(7.0 \%)\end{array}$ & $\begin{array}{l}371 \\
(5.4 \%)\end{array}$ \\
\hline $\begin{array}{l}\text { Atrial } \\
\text { fibrillation }\end{array}$ & $\begin{array}{l}6578 \\
(20.4 \%)\end{array}$ & $\begin{array}{l}896 \\
(28.2 \%)\end{array}$ & $\begin{array}{l}765 \\
(23.9 \%)\end{array}$ & $\begin{array}{l}851 \\
(20.3 \%)\end{array}$ & $\begin{array}{l}942 \\
(19.9 \%)\end{array}$ & $\begin{array}{l}557 \\
(20.1 \%)\end{array}$ & $\begin{array}{l}638 \\
(19.8 \%)\end{array}$ & $\begin{array}{l}714 \\
(17.7 \%)\end{array}$ & $\begin{array}{l}1215 \\
(17.5 \%)\end{array}$ \\
\hline Initial S02<90\% & $\begin{array}{l}991 \\
(3.1 \%)\end{array}$ & $\begin{array}{l}135 \\
(4.2 \%)\end{array}$ & $\begin{array}{l}100 \\
(3.1 \%)\end{array}$ & $\begin{array}{l}116 \\
(2.8 \%)\end{array}$ & $\begin{array}{l}153 \\
(3.2 \%)\end{array}$ & $\begin{array}{l}90 \\
(3.2 \%)\end{array}$ & $\begin{array}{l}87 \\
(2.7 \%)\end{array}$ & $\begin{array}{l}134 \\
(3.3 \%)\end{array}$ & $\begin{array}{l}176 \\
(2.5 \%)\end{array}$ \\
\hline ACEI & $\begin{array}{l}7445 \\
(23.1 \%)\end{array}$ & $\begin{array}{l}745 \\
(23.4 \%)\end{array}$ & $\begin{array}{l}772 \\
(24.1 \%)\end{array}$ & $\begin{array}{l}924 \\
(22.0 \%)\end{array}$ & $\begin{array}{l}1049 \\
(22.1 \%)\end{array}$ & $\begin{array}{l}673 \\
(24.3 \%)\end{array}$ & $\begin{array}{l}768 \\
(23.9 \%)\end{array}$ & $\begin{array}{l}940 \\
(23.3 \%)\end{array}$ & $\begin{array}{l}1574 \\
(22.7 \%)\end{array}$ \\
\hline ARB & $\begin{array}{l}8602 \\
(26.7 \%)\end{array}$ & $\begin{array}{l}803 \\
(25.3 \%)\end{array}$ & $\begin{array}{l}836 \\
(26.1 \%)\end{array}$ & $\begin{array}{l}1120 \\
(26.7 \%)\end{array}$ & $\begin{array}{l}1274 \\
(26.9 \%)\end{array}$ & $\begin{array}{l}737 \\
(26.6 \%)\end{array}$ & $\begin{array}{l}805 \\
(25.0 \%)\end{array}$ & $\begin{array}{l}1084 \\
(26.9 \%)\end{array}$ & $\begin{array}{l}1943 \\
(28.1 \%)\end{array}$ \\
\hline$\beta$-blocker & $\begin{array}{l}17298 \\
(53.6 \%)\end{array}$ & $\begin{array}{l}1744 \\
(54.9 \%)\end{array}$ & $\begin{array}{l}1720 \\
(53.8 \%)\end{array}$ & $\begin{array}{l}2231 \\
(53.2 \%)\end{array}$ & $\begin{array}{l}2515 \\
(53.1 \%)\end{array}$ & $\begin{array}{l}1445 \\
(52.2 \%)\end{array}$ & $\begin{array}{l}1691 \\
(52.6 \%)\end{array}$ & $\begin{array}{l}2202 \\
(54.7 \%)\end{array}$ & $\begin{array}{l}3750 \\
(54.1 \%)\end{array}$ \\
\hline CCB & $\begin{array}{l}9828 \\
(30.5 \%)\end{array}$ & $\begin{array}{l}947 \\
(29.8 \%)\end{array}$ & $\begin{array}{l}955 \\
(29.9 \%)\end{array}$ & $\begin{array}{l}1240 \\
(29.6 \%)\end{array}$ & $\begin{array}{l}1404 \\
(29.6 \%)\end{array}$ & $\begin{array}{l}847 \\
(30.6 \%)\end{array}$ & $\begin{array}{l}1018 \\
(31.6 \%)\end{array}$ & $\begin{array}{l}1245 \\
(30.9 \%)\end{array}$ & $\begin{array}{l}2172 \\
(31.4 \%)\end{array}$ \\
\hline Diuretics & $\begin{array}{l}17667 \\
(54.8 \%)\end{array}$ & $\begin{array}{l}1740 \\
(54.8 \%)\end{array}$ & $\begin{array}{l}1746 \\
(54.6 \%)\end{array}$ & $\begin{array}{l}2229 \\
(53.2 \%)\end{array}$ & $\begin{array}{l}2562 \\
(54.1 \%)\end{array}$ & $\begin{array}{l}1475 \\
(53.2 \%)\end{array}$ & $\begin{array}{l}1745 \\
(54.2 \%)\end{array}$ & $\begin{array}{l}2275 \\
(56.5 \%)\end{array}$ & $\begin{array}{l}3895 \\
(56.2 \%)\end{array}$ \\
\hline Statins & $\begin{array}{l}12580 \\
(39.0 \%)\end{array}$ & $\begin{array}{l}1181 \\
(37.2 \%)\end{array}$ & $\begin{array}{l}1272 \\
(39.8 \%)\end{array}$ & $\begin{array}{l}1541 \\
(36.8 \%)\end{array}$ & $\begin{array}{l}1810 \\
(38.2 \%)\end{array}$ & $\begin{array}{l}1077 \\
(38.9 \%)\end{array}$ & $\begin{array}{l}1328 \\
(41.3 \%)\end{array}$ & $\begin{array}{l}1569 \\
(39.0 \%)\end{array}$ & $\begin{array}{l}2802 \\
(40.5 \%)\end{array}$ \\
\hline
\end{tabular}


medRxiv preprint doi: https://doi.org/10.1101/2021.12.22.21268237; this version posted December 27, 2021. The copyright holder for this preprint (which was not certified by peer review) is the author/funder, who has granted medRxiv a license to display the preprint in perpetuity.

It is made available under a CC-BY-NC-ND 4.0 International license .

\begin{tabular}{|c|c|c|c|c|c|c|c|c|c|}
\hline Warfarin & $\begin{array}{l}2440 \\
(7.6 \%)\end{array}$ & $\begin{array}{l}282 \\
(8.9 \%)\end{array}$ & $\begin{array}{l}252 \\
(7.9 \%)\end{array}$ & $\begin{array}{l}302 \\
(7.2 \%)\end{array}$ & $\begin{array}{l}361 \\
(7.6 \%)\end{array}$ & $\begin{array}{l}188 \\
(6.8 \%)\end{array}$ & $\begin{array}{l}283 \\
(8.8 \%)\end{array}$ & $\begin{array}{l}312 \\
(7.7 \%)\end{array}$ & $\begin{array}{l}460 \\
(6.6 \%)\end{array}$ \\
\hline LMWH & $\begin{array}{l}5960 \\
(18.5 \%)\end{array}$ & $\begin{array}{l}622 \\
(19.6 \%)\end{array}$ & $\begin{array}{l}598 \\
(18.7 \%)\end{array}$ & $\begin{array}{l}786 \\
(18.8 \%)\end{array}$ & $\begin{array}{l}798 \\
(16.8 \%)\end{array}$ & $\begin{array}{l}584 \\
(21.1 \%)\end{array}$ & $\begin{array}{l}643 \\
(20.0 \%)\end{array}$ & $\begin{array}{l}783 \\
(19.4 \%)\end{array}$ & $\begin{array}{l}1146 \\
(16.5 \%)\end{array}$ \\
\hline NOAC & $\begin{array}{l}9975 \\
(30.9 \%)\end{array}$ & $\begin{array}{l}942 \\
(29.7 \%)\end{array}$ & $\begin{array}{l}1012 \\
(31.6 \%)\end{array}$ & $\begin{array}{l}1245 \\
(29.7 \%)\end{array}$ & $\begin{array}{l}1463 \\
(30.9 \%)\end{array}$ & $\begin{array}{l}846 \\
(30.5 \%)\end{array}$ & $\begin{array}{l}959 \\
(29.8 \%)\end{array}$ & $\begin{array}{l}1245 \\
(30.9 \%)\end{array}$ & $\begin{array}{l}2263 \\
(32.7 \%)\end{array}$ \\
\hline Glucocorticoids & $\begin{array}{l}5426 \\
(16.8 \%)\end{array}$ & $\begin{array}{l}585 \\
(18.4 \%)\end{array}$ & $\begin{array}{l}515 \\
(16.1 \%)\end{array}$ & $\begin{array}{l}675 \\
(16.1 \%)\end{array}$ & $\begin{array}{l}802 \\
(16.9 \%)\end{array}$ & $\begin{array}{l}439 \\
(15.8 \%)\end{array}$ & $\begin{array}{l}521 \\
(16.2 \%)\end{array}$ & $\begin{array}{l}669 \\
(16.6 \%)\end{array}$ & $\begin{array}{l}1220 \\
(17.6 \%)\end{array}$ \\
\hline Antibiotics & $\begin{array}{l}11154 \\
(34.6 \%)\end{array}$ & $\begin{array}{l}1071 \\
(33.7 \%)\end{array}$ & $\begin{array}{l}1000 \\
(31.3 \%)\end{array}$ & $\begin{array}{l}1360 \\
(32.5 \%)\end{array}$ & $\begin{array}{l}1547 \\
(32.7 \%)\end{array}$ & $\begin{array}{l}986 \\
(35.6 \%)\end{array}$ & $\begin{array}{l}1111 \\
(34.5 \%)\end{array}$ & $\begin{array}{l}1469 \\
(36.5 \%)\end{array}$ & $\begin{array}{l}2610 \\
(37.7 \%)\end{array}$ \\
\hline $\begin{array}{l}\text { Days of } \\
\text { hospitalization }\end{array}$ & $\begin{array}{l}6.0 \text { (4.0, } \\
9.0)\end{array}$ & $\begin{array}{l}6.0 \text { (4.0, } \\
8.0)\end{array}$ & $\begin{array}{l}7.0 \text { (4.0, } \\
9.0)\end{array}$ & $\begin{array}{l}7.0 \text { (4.0, } \\
9.0)\end{array}$ & $\begin{array}{l}6.0 \text { (4.0, } \\
9.0)\end{array}$ & $\begin{array}{l}7.0(5.0, \\
9.0)\end{array}$ & $\begin{array}{l}7.0 \text { (5.0, } \\
9.0)\end{array}$ & $\begin{array}{l}7.0 \text { (4.0, } \\
9.0)\end{array}$ & $\begin{array}{l}6.0(4.0, \\
8.0)\end{array}$ \\
\hline $\begin{array}{l}\text { 30-day } \\
\text { mortality }\end{array}$ & $\begin{array}{l}2022 \\
(6.3 \%)\end{array}$ & $\begin{array}{l}309 \\
(9.7 \%)\end{array}$ & $\begin{array}{l}199 \\
(6.2 \%)\end{array}$ & $\begin{array}{l}263 \\
(6.3 \%)\end{array}$ & $\begin{array}{l}225 \\
(4.8 \%)\end{array}$ & $\begin{array}{l}193 \\
(7.0 \%)\end{array}$ & $\begin{array}{l}209 \\
(6.5 \%)\end{array}$ & $\begin{array}{l}231 \\
(5.7 \%)\end{array}$ & $\begin{array}{l}393 \\
(5.7 \%)\end{array}$ \\
\hline
\end{tabular}

Abbreviations: S02<90\% peripheral oxygen saturation under 90\%; ACEl, angiotensin-converting enzyme inhibitors; ARB, angiotensin receptor blockers; CCB, calcium channel blockers; LMWH, low-molecular-weight heparin; NOAC, Non-vitamin-K antagonist oral anticoagulant. Days of hospitalization: median number of days hospitalized (interquartile range). 30-day mortality is calculated from the date of hospitalization. 
medRxiv preprint doi: https://doi.org/10.1101/2021.12.22.21268237; this version posted December 27, 2021. The copyright holder for this preprint (which was not certified by peer review) is the author/funder, who has granted medRxiv a license to display the preprint in perpetuity.

It is made available under a CC-BY-NC-ND 4.0 International license .

491

492

Table 2 Odds ratios for 30-day mortality in geriatric patients with COVID-19 and other diagnoses throughout the pandemic.

\begin{tabular}{|c|c|c|c|c|}
\hline & COVID-19 & & Non-COVID & \\
\hline & OR & $95 \% \mathrm{Cl}$ & OR & $95 \% \mathrm{Cl}$ \\
\hline Mar-Apr 2020 & $1.92^{* * *}$ & $1.55,2.37$ & $1.33^{* *}$ & $1.10,1.61$ \\
\hline May-June 2020 & 0.91 & $0.72,1.17$ & 0.85 & $0.69,1.05$ \\
\hline July-Aug 2020 & $0.31 * *$ & $0.15,0.66$ & 0.90 & $0.74,1.09$ \\
\hline Sep-Oct 2020 & 0.99 & $0.59,1.64$ & $0.67^{* * *}$ & $0.55,0.82$ \\
\hline Nov-Dec 2020 & ref & & ref & \\
\hline Jan-Feb 2021 & $0.70^{* *}$ & $0.54,0.91$ & 0.93 & $0.76,1.14$ \\
\hline Mar-Apr 2021 & $0.72 *$ & $0.55,0.94$ & $0.81^{*}$ & $0.67,0.99$ \\
\hline May-June-July 2021 & 0.75 & $0.49,1.13$ & $0.82^{*}$ & $0.69,0.98$ \\
\hline \multicolumn{5}{|l|}{ Age } \\
\hline $70-79$ & ref & & ref & \\
\hline $80-89$ & $2.05^{* * *}$ & $1.68,2.51$ & $1.62^{* * *}$ & $1.42,1.85$ \\
\hline $90+$ & $3.06^{* * *}$ & $2.45,3.82$ & $2.42^{* * *}$ & $2.11,2.77$ \\
\hline Women & $0.63^{* * *}$ & $0.54,0.74$ & $0.68^{* * *}$ & $0.62,0.75$ \\
\hline $\mathrm{CCl}$ & $1.16^{* * *}$ & $1.12,1.20$ & $1.18^{* * *}$ & $1.16,1.21$ \\
\hline ACEI & 0.94 & $0.78,1.14$ & $0.84 * *$ & $0.75,0.94$ \\
\hline ARB & 0.84 & $0.70,1.01$ & $0.72^{* * *}$ & $0.64,0.80$ \\
\hline$\beta$-blocker & $1.20^{*}$ & \begin{tabular}{|l|}
$1.02,1.41$ \\
\end{tabular} & $1.25^{* * *}$ & $1.13,1.39$ \\
\hline CCB & $0.80^{*}$ & $0.68,0.95$ & $0.72^{* * *}$ & $0.65,0.80$ \\
\hline Diuretics & $1.32 * * *$ & $1.12,1.55$ & $1.49 * * *$ & $1.34,1.65$ \\
\hline Statins & $0.70 * * *$ & $0.59,0.82$ & $0.74^{* * *}$ & $0.66,0.82$ \\
\hline Warfarin & 1.15 & $0.87,1.52$ & 1.06 & $0.91,1.25$ \\
\hline LMWH & 1.06 & $0.88,1.26$ & $1.23 * * *$ & $1.10,1.38$ \\
\hline NOAC & 0.93 & $0.77,1.13$ & 0.98 & $0.88,1.08$ \\
\hline Glucocorticoids & $1.22 *$ & $1.03,1.45$ & $1.18^{* *}$ & $1.05,1.33$ \\
\hline Antibiotic & $1.51^{* * *}$ & $1.29,1.75$ & $1.27^{* * *}$ & $1.16,1.40$ \\
\hline
\end{tabular}


medRxiv preprint doi: https://doi.org/10.1101/2021.12.22.21268237; this version posted December 27, 2021. The copyright holder for this preprint (which was not certified by peer review) is the author/funder, who has granted medRxiv a license to display the preprint in perpetuity.

It is made available under a CC-BY-NC-ND 4.0 International license .

\section{Figure 1 Case selection flow chart}

497

498

499

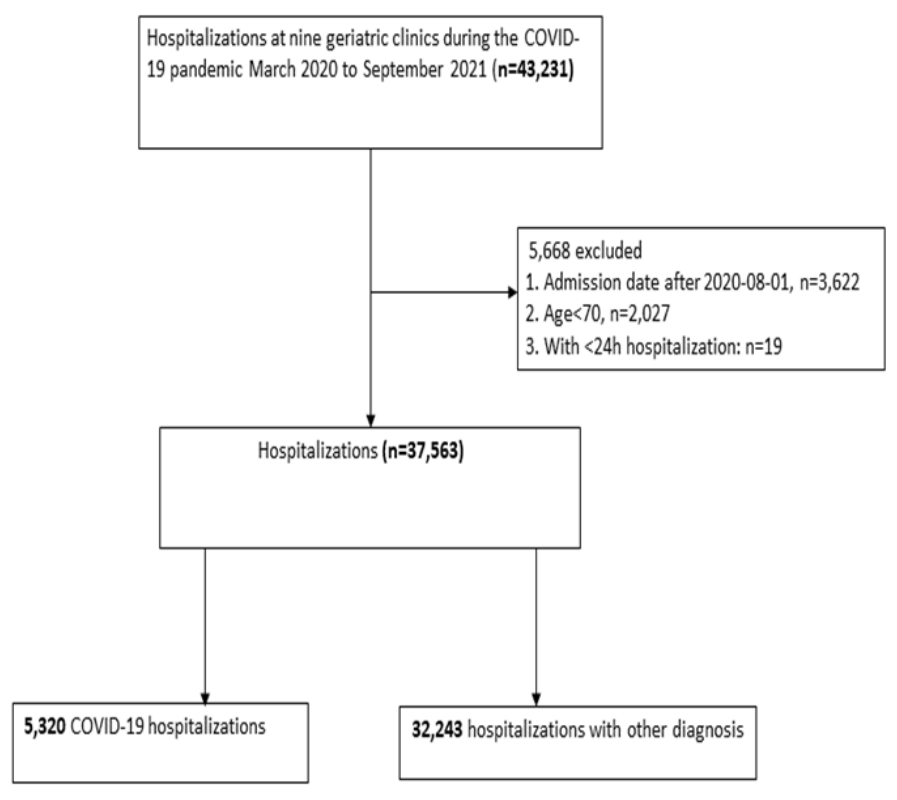


medRxiv preprint doi: https://doi.org/10.1101/2021.12.22.21268237; this version posted December 27, 2021. The copyright holder for this preprint (which was not certified by peer review) is the author/funder, who has granted medRxiv a license to display the preprint in perpetuity.

It is made available under a CC-BY-NC-ND 4.0 International license .

500 Figure 2 Hospitalizations and mortality throughout the COVID-19 pandemic for 501 persons aged 70 and above

502 A) Number of weekly hospitalizations of patients 70 and above in nine geriatric clinics in Stockholm from 503 March 2020 to July 2021.

504

505

506

507

508

509

510

511

512

513

514

515

516
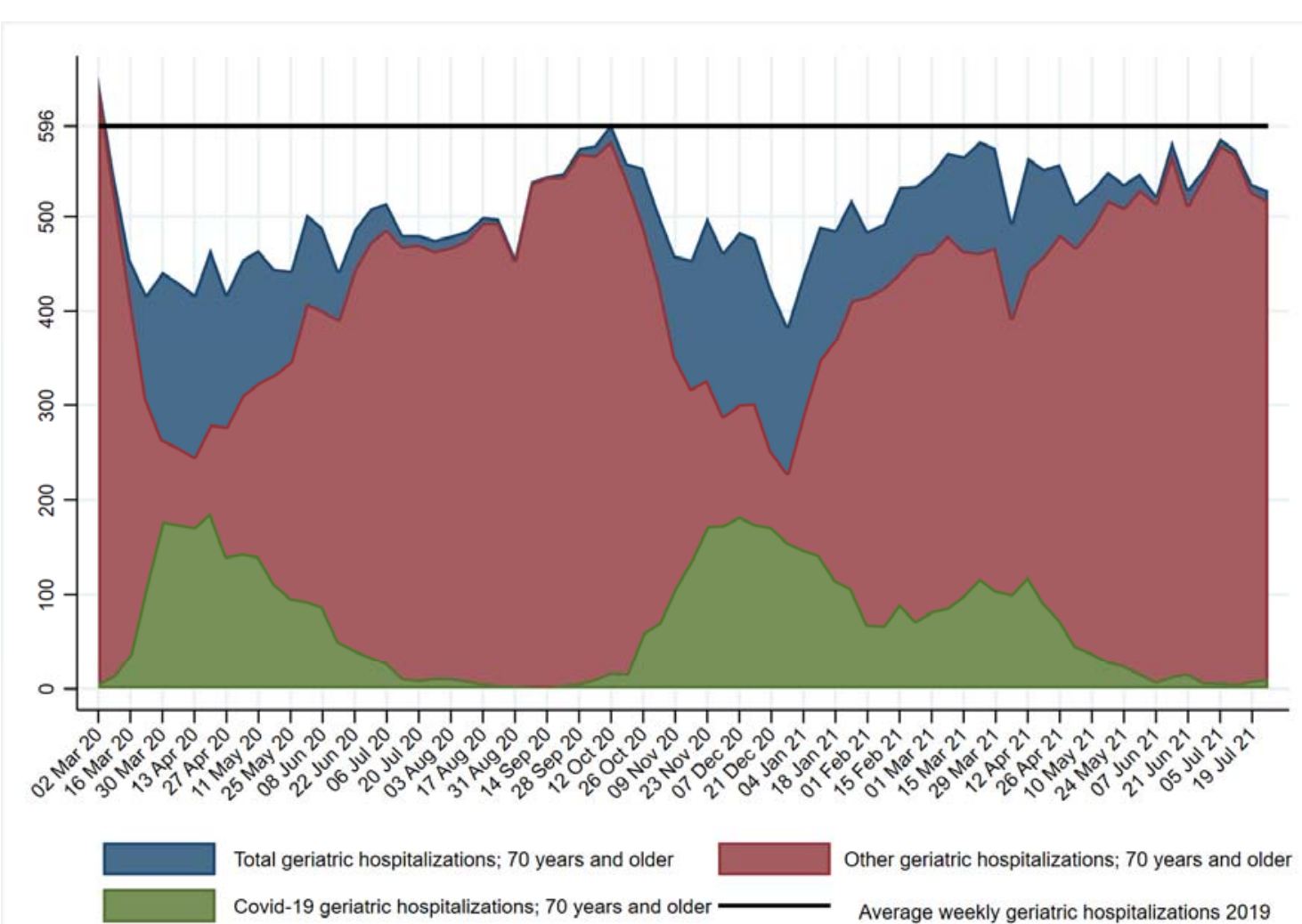

Total geriatric hospitalizations; 70 years and older

Other geriatric hospitalizations; 70 years and older

Covid-19 geriatric hospitalizations; 70 years and older

Average weekly geriatric hospitalizations 2019 
medRxiv preprint doi: https://doi.org/10.1101/2021.12.22.21268237; this version posted December 27, 2021. The copyright holder for this preprint (which was not certified by peer review) is the author/funder, who has granted medRxiv a license to display the preprint in perpetuity.

It is made available under a CC-BY-NC-ND 4.0 International license .

517

518

519

520

B) 30-day COVID-19 mortality in relationship to weekly hospitalizations in geriatric clinics in patients 70 and above

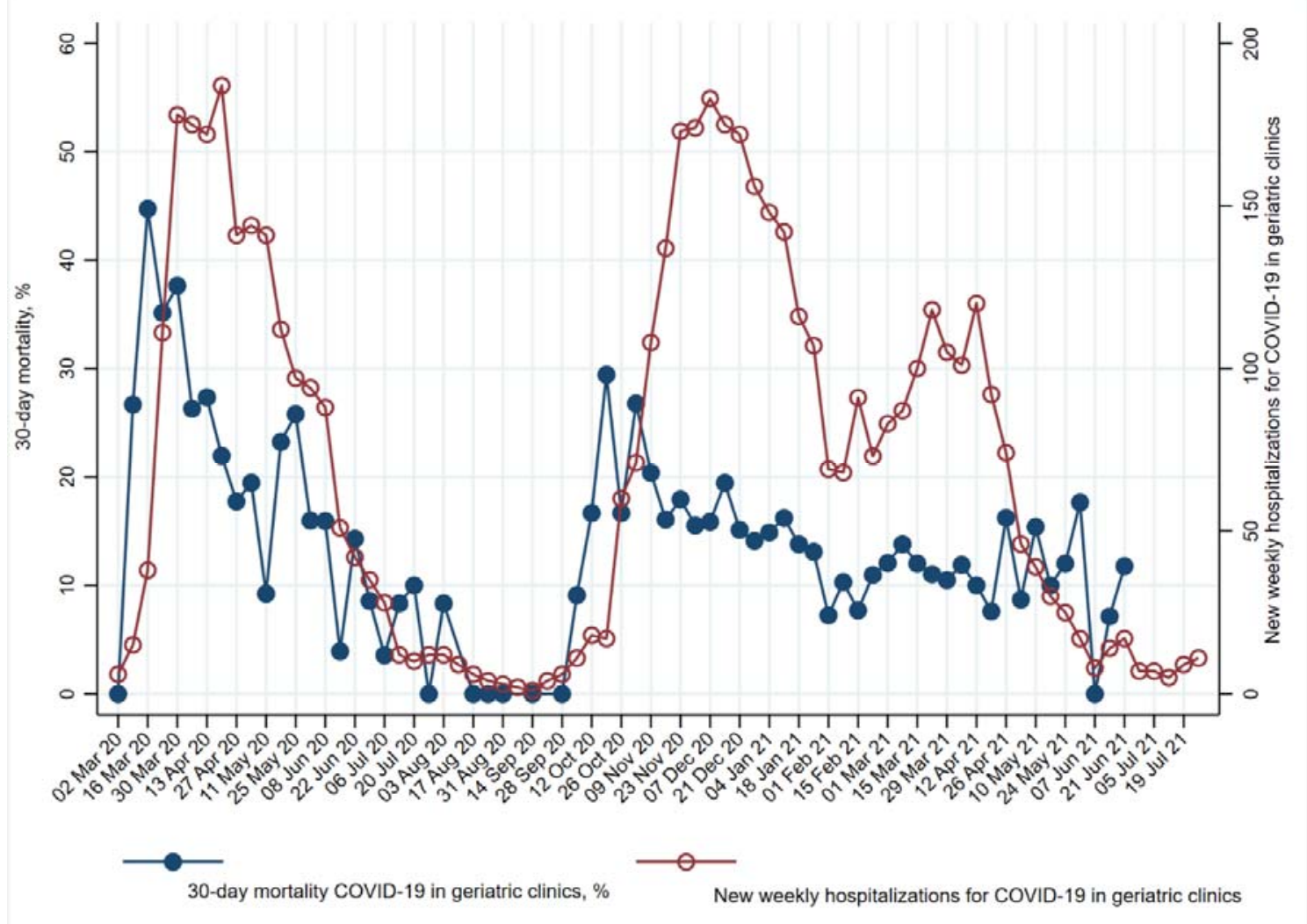


medRxiv preprint doi: https://doi.org/10.1101/2021.12.22.21268237; this version posted December 27, 2021. The copyright holder for this preprint (which was not certified by peer review) is the author/funder, who has granted medRxiv a license to display the preprint in perpetuity.

It is made available under a CC-BY-NC-ND 4.0 International license .

521

522

523

524

525

526

527

528

529

530

531

532

533

534

535

536

537
C) 30-day mortality and hospitalizations for non-COVID causes in geriatric clinics for patients 70 and over

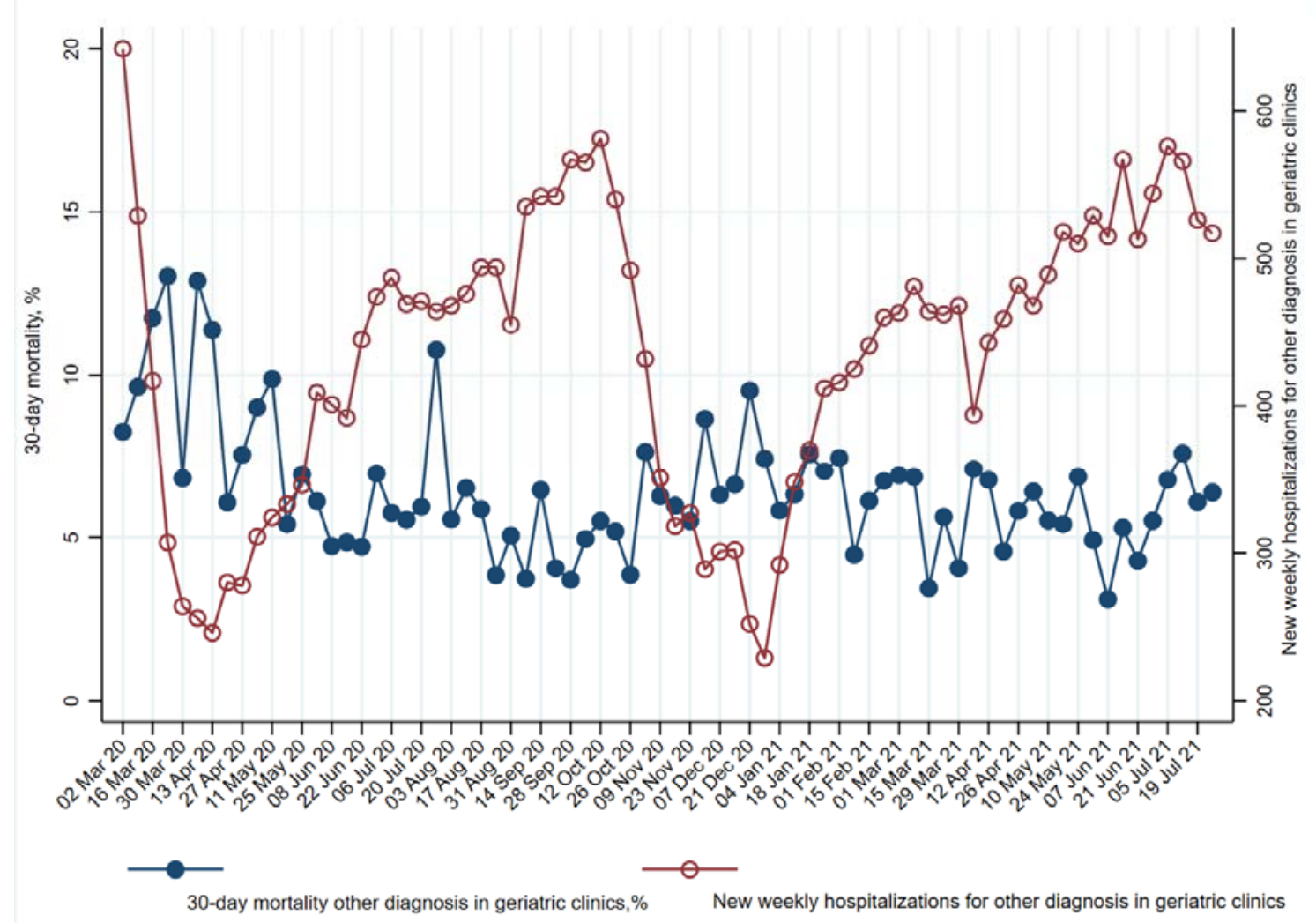


medRxiv preprint doi: https://doi.org/10.1101/2021.12.22.21268237; this version posted December 27, 2021. The copyright holder for this preprint (which was not certified by peer review) is the author/funder, who has granted medRxiv a license to display the preprint in perpetuity.

It is made available under a CC-BY-NC-ND 4.0 International license .

538

539

Figure 3. Relationship between confirmed cases of COVID-19, hospitalizations, and deaths in Stockholm

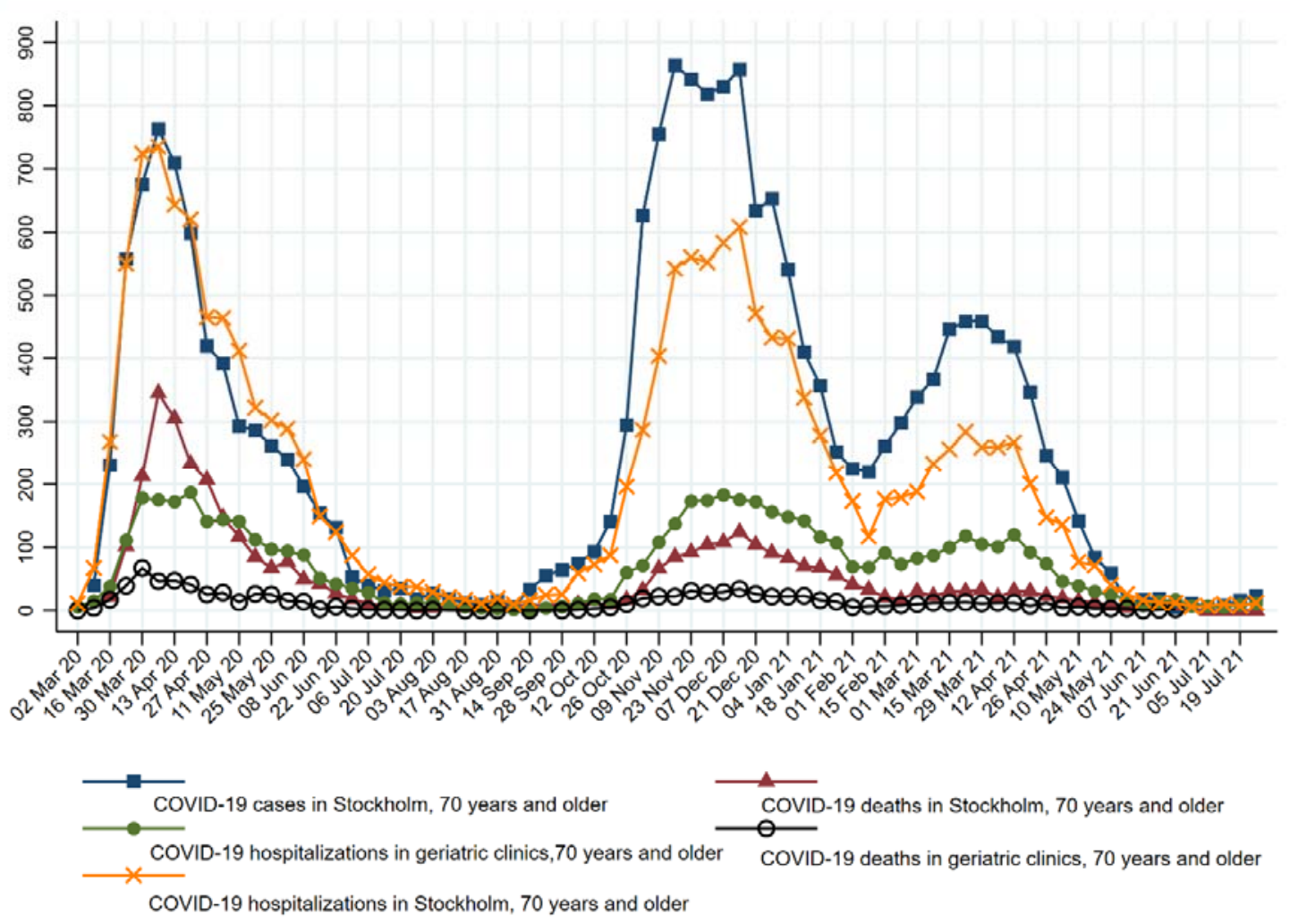

540

541

542

543

544

545

546

547

548

549

550

551

552

553

554

555

556

557

558 
eTable 1 COVID-19 cases, mortality and hospitalizations in Stockholm and in geriatric clinics for population 70 and above.

\begin{tabular}{|c|c|c|c|c|c|c|c|c|c|}
\hline Week & $\begin{array}{l}\text { COVID-19 } \\
\text { positive } \\
\text { cases in } \\
\text { Stockholm }\end{array}$ & $\begin{array}{l}\text { 30-day } \\
\text { COVID-19 } \\
\text { mortality } \\
\text { Stockholm }\end{array}$ & $\begin{array}{l}\text { COVID-19 } \\
\text { hospitalizations } \\
\text { in Stockholm }\end{array}$ & $\begin{array}{l}\text { Total } \\
\text { hospitalizations } \\
\text { in Stockholm }\end{array}$ & \begin{tabular}{|l|} 
COVID-19 \\
geriatric \\
hospitalizations
\end{tabular} & $\begin{array}{l}\text { 30-day } \\
\text { mortality after } \\
\text { geriatric } \\
\text { hospitalization } \\
\text { for COVID-19 }\end{array}$ & $\begin{array}{l}\text { Other } \\
\text { diagnoses, } \\
\text { geriatric } \\
\text { hospitalizations }\end{array}$ & $\begin{array}{l}\text { 30-day } \\
\text { mortality after } \\
\text { geriatric } \\
\text { hospitalization, } \\
\text { non-COVID-19 }\end{array}$ & $\begin{array}{l}\text { Total geriatric } \\
\text { hospitalizations }\end{array}$ \\
\hline March 1, 2020 & & & & & & & 28 & 3 & 28 \\
\hline March 2, 2020 & & & 11 & 2718 & 6 & 0 & 642 & 53 & 648 \\
\hline March 9, 2020 & 40 & $x$ & 67 & 2515 & 15 & 4 & 529 & 51 & 544 \\
\hline March 16, 2020 & 231 & 22 & 268 & 2364 & 38 & 17 & 417 & 49 & 455 \\
\hline March 23, 2020 & 557 & 102 & 550 & 2237 & 111 & 39 & 307 & 40 & 418 \\
\hline March 30, 2020 & 675 & 213 & 724 & 2130 & 178 & 67 & 264 & 18 & 442 \\
\hline April 6, 2020 & 763 & 345 & 735 & 2120 & 175 & 46 & 256 & 33 & 431 \\
\hline April 13, 2020 & 709 & 305 & 643 & 2116 & 172 & 47 & 246 & 28 & 418 \\
\hline April 20, 2020 & 598 & 233 & 620 & 2260 & 187 & 41 & 280 & 17 & 467 \\
\hline April 27, 2020 & 420 & 207 & 465 & 2030 & 141 & 25 & 278 & 21 & 419 \\
\hline May 4, 2020 & 392 & 147 & 464 & 2245 & 144 & 28 & 311 & 28 & 455 \\
\hline May 11,2020 & 293 & 117 & 412 & 2120 & 141 & 13 & 324 & 32 & 465 \\
\hline May 18,2020 & 286 & 85 & 322 & 1999 & 112 & 26 & 333 & 18 & 445 \\
\hline May 25, 2020 & 262 & 67 & 302 & 2186 & 97 & 25 & 346 & 24 & 443 \\
\hline June 1,2020 & 240 & 77 & 289 & 2277 & 94 & 15 & 409 & 25 & 503 \\
\hline June 8,2020 & 196 & 49 & 240 & 2320 & 88 & 14 & 401 & 19 & 489 \\
\hline June 15,2020 & 154 & 42 & 149 & 2081 & 51 & 2 & 392 & 19 & 443 \\
\hline June 22,2020 & 131 & 27 & 124 & 2235 & 42 & 6 & 445 & 21 & 487 \\
\hline June 29,2020 & 53 & 18 & 87 & 2187 & 35 & 3 & 474 & 33 & 509 \\
\hline July 6, 2020 & 40 & 11 & 57 & 2125 & 28 & 1 & 487 & 28 & 515 \\
\hline
\end{tabular}




\begin{tabular}{|c|c|c|c|c|c|c|c|c|c|}
\hline July 13, 2020 & 31 & 7 & 44 & 2018 & 12 & 1 & 469 & 26 & 481 \\
\hline July 20, 2020 & 35 & 7 & 38 & 2010 & 10 & 1 & 471 & 28 & 481 \\
\hline July 27,2020 & 18 & 4 & 37 & 2078 & 12 & 0 & 464 & 50 & 476 \\
\hline August 3, 2020 & 27 & 5 & 29 & 2136 & 12 & 1 & 468 & 26 & 480 \\
\hline August 10, 2020 & 19 & $\mathrm{x}$ & 21 & 2145 & 9 & $\mathrm{x}$ & 476 & 31 & 485 \\
\hline August 17, 2020 & 12 & 5 & 17 & 2336 & 6 & 0 & 494 & 29 & 500 \\
\hline August 24, 2020 & 9 & $\mathrm{X}$ & 11 & 2453 & 4 & 0 & 494 & 19 & 498 \\
\hline August 31, 2020 & 15 & $\mathrm{x}$ & 19 & 2420 & 3 & 0 & 455 & 23 & 458 \\
\hline $\begin{array}{l}\text { September 7, } \\
2020\end{array}$ & 6 & $x$ & 10 & 2552 & 2 & $\mathrm{x}$ & 535 & 20 & 537 \\
\hline $\begin{array}{l}\text { September 14, } \\
2020\end{array}$ & 33 & $x$ & 16 & 2567 & 1 & 0 & 542 & 35 & 543 \\
\hline $\begin{array}{l}\text { September 21, } \\
2020\end{array}$ & 55 & $x$ & 24 & 2552 & 4 & $\mathrm{x}$ & 542 & 22 & 546 \\
\hline $\begin{array}{l}\text { September } 28, \\
2020\end{array}$ & 64 & $x$ & 25 & 2673 & 6 & 0 & 567 & 21 & 573 \\
\hline October 5, 2020 & 74 & 10 & 59 & 2726 & 11 & 1 & 565 & 28 & 576 \\
\hline $\begin{array}{l}\text { October 12, } \\
2020\end{array}$ & 93 & $x$ & 73 & 2655 & 18 & 3 & 581 & 32 & 599 \\
\hline $\begin{array}{l}\text { October 19, } \\
2020\end{array}$ & 141 & 10 & 87 & 2592 & 17 & 5 & 540 & 28 & 557 \\
\hline $\begin{array}{l}\text { October 26, } \\
2020\end{array}$ & 295 & 17 & 196 & 2683 & 60 & 10 & 492 & 19 & 552 \\
\hline $\begin{array}{l}\text { November 2, } \\
2020\end{array}$ & 626 & 32 & 287 & 2545 & 71 & 19 & 432 & 33 & 503 \\
\hline $\begin{array}{l}\text { November 9, } \\
2020\end{array}$ & 755 & 66 & 404 & 2433 & 108 & 22 & 351 & 22 & 459 \\
\hline $\begin{array}{l}\text { November 16, } \\
2020\end{array}$ & 864 & 85 & 542 & 2565 & 137 & 22 & 318 & 19 & 455 \\
\hline
\end{tabular}




\begin{tabular}{|c|c|c|c|c|c|c|c|c|c|}
\hline $\begin{array}{l}\text { November 23, } \\
2020\end{array}$ & 842 & 92 & 560 & 2579 & 173 & 31 & 327 & 18 & 500 \\
\hline $\begin{array}{l}\text { November 30, } \\
2020\end{array}$ & 818 & 104 & 552 & 2596 & 174 & 27 & 289 & 25 & 463 \\
\hline $\begin{array}{l}\text { December 7, } \\
2020\end{array}$ & 830 & 108 & 583 & 2680 & 183 & 29 & 301 & 19 & 484 \\
\hline $\begin{array}{l}\text { December 14, } \\
2020\end{array}$ & 857 & 124 & 608 & 2590 & 175 & 34 & 302 & 20 & 477 \\
\hline $\begin{array}{l}\text { December 21, } \\
2020\end{array}$ & 634 & 104 & 471 & 2247 & 172 & 26 & 252 & 24 & 424 \\
\hline $\begin{array}{l}\text { December 28, } \\
2020\end{array}$ & 653 & 91 & 433 & 2308 & 156 & 22 & 229 & 17 & 385 \\
\hline January 4, 2021 & 540 & 83 & 431 & 2361 & 148 & 22 & 292 & 17 & 440 \\
\hline $\begin{array}{l}\text { January 11, } \\
2021\end{array}$ & 410 & 70 & 338 & 2501 & 142 & 23 & 348 & 22 & 490 \\
\hline $\begin{array}{l}\text { January 18, } \\
2021\end{array}$ & 357 & 68 & 278 & 2512 & 116 & 16 & 370 & 28 & 486 \\
\hline $\begin{array}{l}\text { January 25, } \\
2021\end{array}$ & 252 & 56 & 218 & 2475 & 107 & 14 & 412 & 29 & 519 \\
\hline $\begin{array}{l}\text { February 1, } \\
2021\end{array}$ & 225 & 41 & 173 & 2403 & 69 & 5 & 416 & 31 & 485 \\
\hline $\begin{array}{l}\text { February 8, } \\
2021\end{array}$ & 220 & 33 & 117 & 2363 & 68 & 7 & 425 & 19 & 493 \\
\hline $\begin{array}{l}\text { February 15, } \\
2021\end{array}$ & 261 & 21 & 176 & 2513 & 91 & 7 & 441 & 27 & 532 \\
\hline $\begin{array}{l}\text { February 22, } \\
2021\end{array}$ & 298 & 17 & 179 & 2504 & 73 & 8 & 460 & 31 & 533 \\
\hline March 1, 2021 & 339 & 30 & 188 & 2446 & 83 & 10 & 463 & 32 & 546 \\
\hline March 8, 2021 & 367 & 23 & 233 & 2576 & 87 & 12 & 481 & 33 & 568 \\
\hline March 15, 2021 & 446 & 30 & 256 & 2510 & 100 & 12 & 464 & 16 & 564 \\
\hline
\end{tabular}




\begin{tabular}{|c|c|c|c|c|c|c|c|c|c|}
\hline March 22, 2021 & 459 & 30 & 284 & 2664 & 118 & 13 & 462 & 26 & 580 \\
\hline March 29, 2021 & 459 & 33 & 259 & 2337 & 105 & 11 & 468 & 19 & 573 \\
\hline April 5, 2021 & 434 & 21 & 259 & 2357 & 101 & 12 & 394 & 28 & 495 \\
\hline April 12, 2021 & 419 & 31 & 267 & 2435 & 120 & 12 & 443 & 30 & 563 \\
\hline April 19, 2021 & 347 & 30 & 201 & 2376 & 92 & 7 & 459 & 21 & 551 \\
\hline April 26, 2021 & 246 & 23 & 147 & 2463 & 74 & 12 & 482 & 28 & 556 \\
\hline May 3, 2021 & 211 & 19 & 136 & 2529 & 46 & 4 & 468 & 30 & 514 \\
\hline May 10, 2021 & 142 & 15 & 77 & 2318 & 39 & 6 & 489 & 27 & 528 \\
\hline May 17, 2021 & 84 & 13 & 71 & 2582 & 30 & 3 & 518 & 28 & 548 \\
\hline May 24, 2021 & 59 & 8 & 40 & 2469 & 25 & 3 & 510 & 35 & 535 \\
\hline May 31, 2021 & 12 & 5 & 26 & 2537 & 17 & 3 & 529 & 26 & 546 \\
\hline June 7,2021 & 17 & $x$ & 16 & 2462 & 8 & 0 & 515 & 16 & 523 \\
\hline June 14, 2021 & 19 & $x$ & 12 & 2553 & 14 & 1 & 567 & 30 & 581 \\
\hline June 21, 2021 & 5 & $x$ & 12 & 2289 & 17 & 2 & 513 & 22 & 530 \\
\hline June 28,2021 & 11 & $x$ & 6 & 2362 & 7 & $x$ & 544 & 30 & 551 \\
\hline July 5, 2021 & 6 & 0 & 7 & 2271 & 7 & $x$ & 576 & 39 & 583 \\
\hline July 12, 2021 & 8 & 0 & 10 & 2107 & 5 & $x$ & 566 & 43 & 571 \\
\hline July 19, 2021 & 16 & 0 & 7 & 2105 & 9 & $\mathrm{x}$ & 526 & 32 & 535 \\
\hline July 26,2021 & 23 & 0 & 12 & 2134 & 11 & $x$ & 517 & 33 & 528 \\
\hline
\end{tabular}

